\title{
Addressing the Desert Kites Phenomenon and Its Global Range Through a Multi-proxy Approach
}

\author{
Rémy Crassard • Olivier Barge • Charles-Edmond Bichot • \\ Jacques Élie Brochier • Jwana Chahoud • \\ Marie-Laure Chambrade • Christine Chataigner • \\ Kamel Madi • Emmanuelle Régagnon • Hamida Seba • \\ Emmanuelle Vila
}

Published online: 23 August 2014

(C) Springer Science+Business Media New York 2014

\begin{abstract}
This paper argues that the wide geographical distribution of desert kites, which are huge archaeological structures of stone visible from satellite images, must be more broadly acknowledged as a momentous factor in the study of their variability and function. This is important so that researchers can more accurately understand and interpret their impact on biodiversity, landscapes and subsistence patterns. The first results and perspectives of the Globalkites research project are discussed and presented. Often considered as hunting traps, the kites could have also been used for animal husbandry. In a broader archaeological context, where kites seem to have been operating from the Neolithic to recent historical times, we propose an interdisciplinary approach at the crossroads of anthropology (archaeology and ethnology), geomatics and Geographic Information Systems (GIS), geostatistics, mathematics and computerized data processing and geoarchaeological and bioarchaeological sciences (isotope studies, paleoclimatology, archaeozoology...). The principal aims of the project are to clearly articulate the variability of the structures and their relationship with the function and chronology of the kites. It is also crucial to discuss the wide distribution of these structures across the Middle East and Central Asia as a global phenomenon and the ideas that explain the dispersal and movements of people and/or traditions must be addressed.
\end{abstract}

R. Crassard $(\bowtie) \cdot$ O. Barge $\cdot$ J. Chahoud $\cdot$ M.-L. Chambrade $\cdot$ C. Chataigner $\cdot$ E. Régagnon $\cdot$ E. Vila CNRS, UMR 5133 'Archéorient', Maison de l’Orient et de la Méditerranée, Lyon, France

e-mail: remy.crassard@mom.fr

C.-E. Bichot

École Centrale de Lyon, UMR 5205 'Liris', Écully, France

J. É. Brochier

Aix-Marseille Université (AMU), CNRS, UMR 7269 'Lampea', Aix-en-Provence, France

K. Madi $\cdot$ H. Seba

Université de Lyon, CNRS, Université Lyon 1 UMR 5205 'Liris', Villeurbanne, France 
Keywords Desert kites · Arid zones · GIS · Geoarchaeology · Hunting · Pastoralism • Interdisciplinary research

\section{Introduction: The Desert Kites Phenomenon and the Globalkites Project}

'Desert kites' (or 'kites') are stone constructions made of two long low walls called antennae (also known as 'guiding walls' or 'tails') that converge into an enclosure (also known as a 'head') flanked or not by several small cells (or compartments, or logettes, also known as 'hides'). The form of the enclosures varies, the antennae can reach a length of several kilometers, while the size of the enclosure itself covers a surface of a few hundred square meters to several hectares. Their distribution over the landscape appears to be discontinuous and their density is very variable: 0.1 kite per $100 \mathrm{~km}^{2}$ in the Negev and Northern Sinai (Holzer et al. 2010) to 50 kites per $100 \mathrm{~km}^{2}$ in some areas of Syria (Échallier and Braemer 1995). 'Desert kites' were discovered in the Near East and hence named by British aeroplane pilots who were flying over the SyrianJordanian desert. Yet their distribution in the Arabian Peninsula has only become a focus of studies during the last few years (Brunner 2008; Skorupka 2010; Kennedy and Bishop 2011). Kites even reach the confines of Uzbekistan (Betts and Yagodin 2000) and the Caucasus (Barge and Brochier 2011; Barge et al. 2013; Gasparyan et al. 2013; Brochier et al. 2014). Other types of trapping structures are known elsewhere: mainly funnel-shaped, lined with wood or stone-lined constructions are known in North Africa, Northern and Southern America and Scandinavia (e.g. Custred 1979; Ingold 1980; Riemer 2009; Benedict 2011; Storemyr 2011; Brink 2013). This 'kites phenomenon' was most probably not either a continuous or a simultaneous process; thus, it therefore covers a wide area. The range of our study is restricted to the Old World, and more precisely, to the Middle East and Central Asia.

Dating kites in these particular regions is still difficult, as few remains were found in what were usually poorly stratified structures or on the surface. The dating of Near Eastern kites ranges from the 7th millennium BC (Helms and Betts 1987) to recent historical periods, as documented by travelers' testimonies (Burckhardt 1831). The very rare radiometric or relative age measurements are the most convincing span from the end of the Chalcolithic to the end of the Bronze Age (Échallier and Braemer 1995; Holzer et al. 2010).

In order to consider kites as a wide range phenomenon, the Globalkites project was developed by an interdisciplinary group of researchers. The project, whose aims and methods will be developed here, covers a large geographical area, with a central spectrum extending to about $600 \mathrm{~km}$ from north to south and $300 \mathrm{~km}$ from west to east (Barge et al. 2013). This particular zone where kites are the most numerous includes southern Syria, eastern Jordan and northern Saudi Arabia. Alongside this Near Eastern core, similar structures were recently discovered in particularly distant regions, such as in Armenia, western Uzbekistan and Kazakhstan, and in Arabia. Observations from satellite imagery have revealed the existence of more than 4,300 structures (Fig. 1; see also the regularly updated and freely accessible interactive map on the website www.globalkites.fr).

Consequently, in the last few years, the number of inventoried kites has increased fivefold and the known distribution zone was greatly extended, suggesting some 


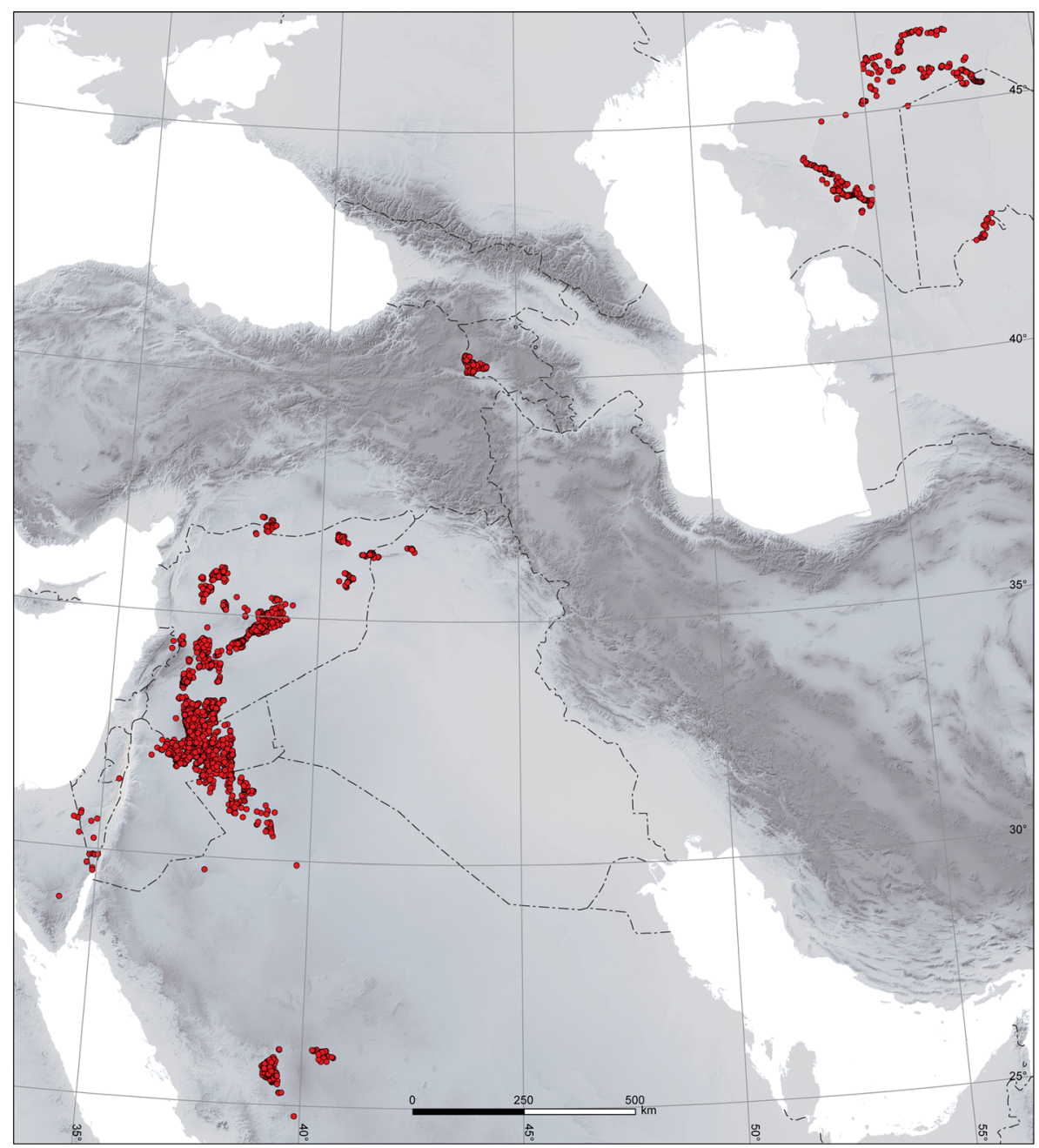

Fig. 1 The inventory of kites at the scale of their distribution area; see also the Globalkites Interactive Map freely accessible at www.globalkites.fr

exceptional potential for in-depth study of this phenomenon. More can therefore be concluded regarding the use of kites across time and space. The main issues that the project concemed itself with relates to the kites' function and their dating: is it possible to distinguish kites used as hunting traps from those meant as corrals for domesticated animals or which are in the process of being used as such? Furthermore, what is the time frame of the use of the kites? Other fundamental issues were also the focus of the project such as the geographical spread and explanations for this extension: either cultural convergence or real interregional technical diffusion? Finally, the adaptive strategies by human groups must be addressed, as should issues of bio-economical regulations in a fragile environment context such as potential overexploitation of wild animal species and the ownership of an exclusive territory by humans.

This paper presents the main (old and new) problems linked to the kite phenomenon, by means of the study of regional faunas and environments. Three fields of approach 
will be presented: geomatics, geoarchaeology and computer sciences. All present and future studies of the Globalkites project will subsequently be based on these analyses and heuristic tools in order to focus on the kite phenomenon in its areas of wide distribution.

\section{The Function of Kites: A Device for Hunting and/or for Animal Husbandry?}

Several theories about the function of kites have been posited since the 1920s. These argued in favor either on their function as hunting traps or on their use for pastoral activities (Rees 1929; Maitland 1927; Fowden 1999). Decades later, the issue is far from being solved. Recent studies consider kites in the Levant in general as mass killing traps for wild game, especially gazelle (Holzer et al. 2010; Bar-Oz et al. 2011; Bar-Oz and Nadel 2013; Zeder et al. 2013). By contrast, earlier studies have elaborated on the progressive and multiple uses of kites. The function of these structures could have shifted from trapping herds to taming wild animals and managing livestock (Échallier and Braemer 1995). In all the cases, the concept, construction and the use of kites suggests the collaboration of either group of people or of a community. These communal activities are reflected by the large number of kites recorded, the wide geographic range of kite dispersal, the size scale of kites, and by their possible function for trapping a large number of animals.

In addition, a wide range of discovered rock art engravings depict 'kite' trapping scenes with animal and human figures (Jordan: Harding 1953; Betts and Helms 1986; Hershkovitz et al. 1987; MacDonald 2005; Syria: Picalause et al. 2004 and Uzbekistan: see Betts and Yagodin 2000). It is nevertheless impossible to identify whether the scenes reflect either the hunting of wild games or the management of livestock (Fig. 2).

\section{The Hunting Model}

Hunting as a possible function for kites reflects community involvement, a preference for hunting traps and the occurrence of wild animals in the vicinity of kites. Travelers' accounts dating to the sixteenth, nineteenth and twentieth centuries describe scenes of gazelles hunting using kite structures in Syria and Jordan (Burckhardt 1831; Wright 1895; Sinclair and Fergusson 1902; Musil 1928; Doughty 1931; Simpson 1994; Jabbur and Conrad 1995; for more details, see Legge and Rowley-Conwy 1987 and Legge and Rowley-Conwy 2000). Meanwhile, ethnographical studies (Fig. 3) refer to Bedouin societies who practice communal hunting using trapping techniques similar to kites and outline the different roles and statuses of hunters, as well as the complexity of mass trapping and killing device. For instance, in the Sahara and in Arabia, nets are used instead of stone-lined kites (Desombre 1946; Chapelle 1957; Sergeant 1976; Bin Aqil 2004; Baroin 2006). These traps made of perishable materials were also used outside the desert zones of Africa (Dupré 1976). This type of hunting recalls a long tradition can be seen in engravings and painted scenes in the Akakus and the Tasili-n-Ajjer (Le Quellec and Civrac 2010).

Much wild game, in terms of ecology and ethology, is likely to be trapped by means of a system of kites: bovids (sheep, goat, aurochs, gazelle, oryx...), equids, camelids and ostriches. These species occur in specific biotopes across the dispersal area of kites from 

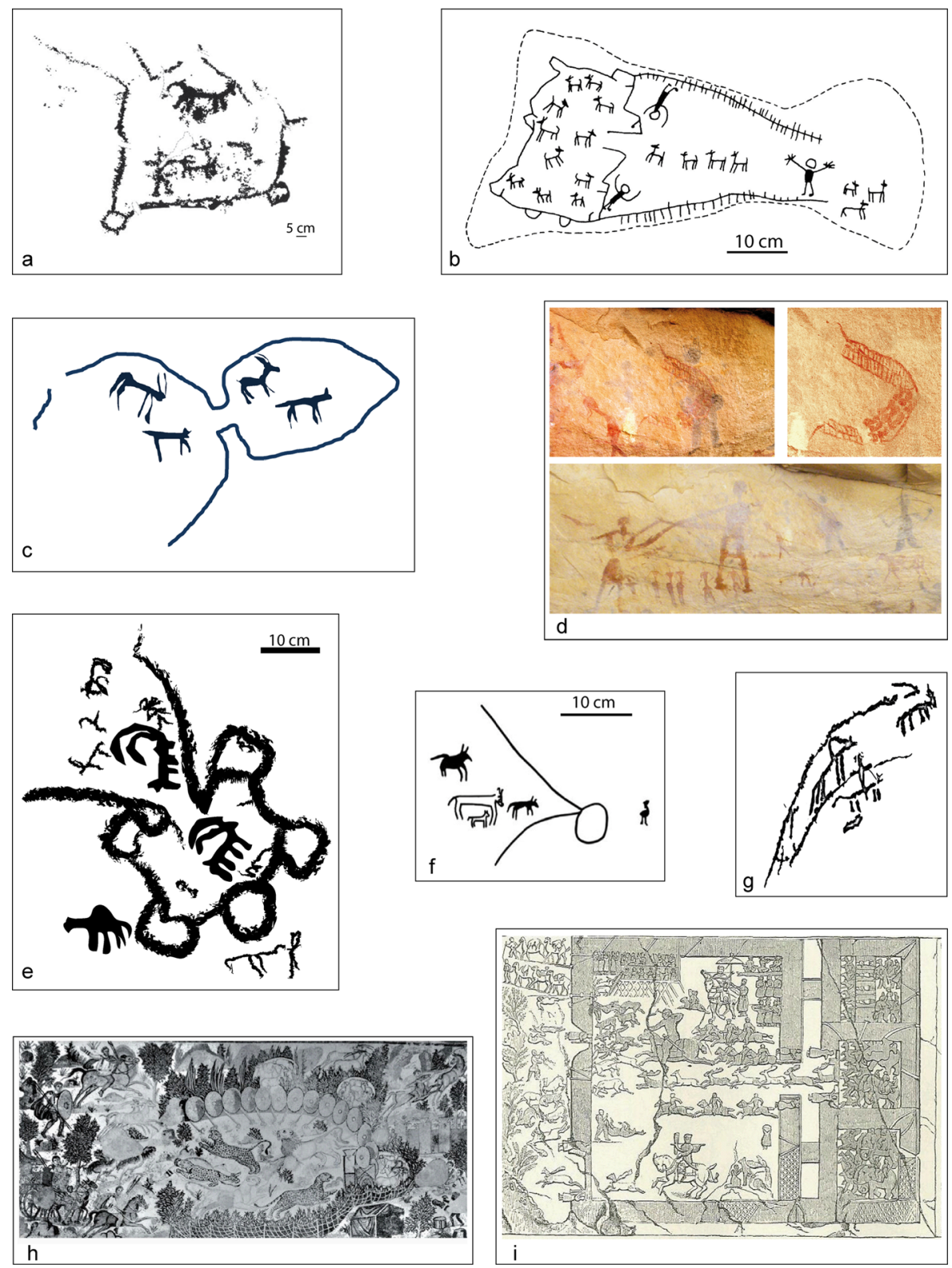

Fig. 2 Rock art: a Khishâm-2, rock B37, Hemma, Syria (Picalause et al. 2004: 2); b drawing of Cairn of Hani rock arts, Jordan (Harding 1954); c tracing panel of rock drawing from Wadi Hashad, northeast Jordan (Hoyland 2001: 95); d painting scene of hunting using nets, Akakus and Tasili-n-Ajjer (Le Quellec and Civrac 2010: 255); e Khishâm-2, rock G28, Hemma, Syria (Picalause et al. 2004: 2); f drawing of rock engravings from Sinai (Bar-Oz and Nadel 2013); g tracing of hunting scene petroglyph, Har Micha, central Negev (Degen 2010: 149); h Hippone mosaic, northeastern Algeria (Fowden 1999: 132); and i drawing of an engraving of Sassanian royal hunt scene of deer in arteficial compound, Iran (Reed 1965)

the deserts (Arabia, Jordan), steppes (Syria) and the semi-arid plateaus (Transcaucasia) to Mediterranean ecosystems (the Levant), and mountainous zones (e.g. Transcaucasia). 

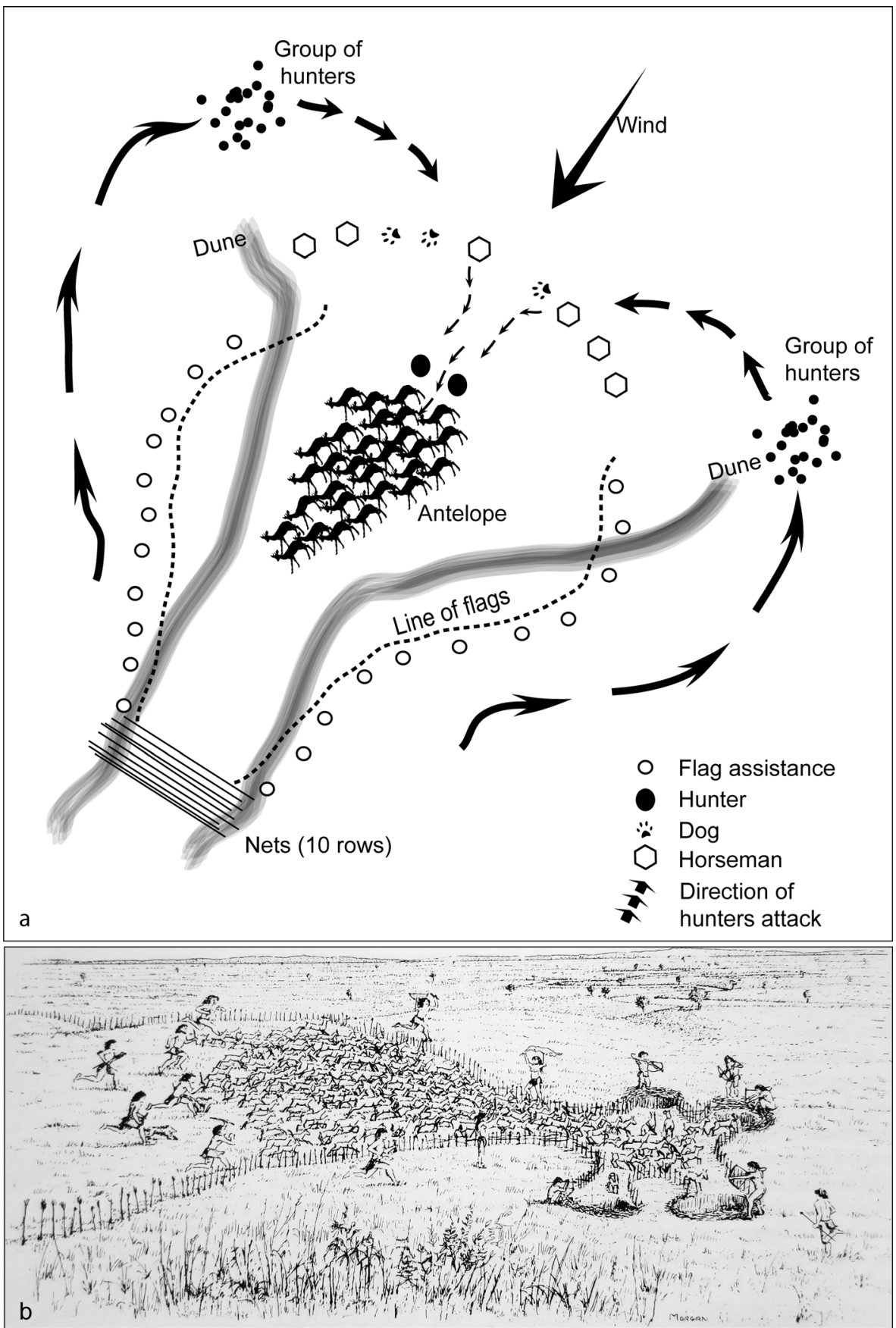

Fig. 3 Ethnographical observation: a hunting traps according to Toubou tribes, Sahara (after Baroin 2006: 39) and $\mathbf{b}$ reconstruction of a gazelle hunt at Abu Hureyra, Syria (Legge and Rowley-Conwy 2000)

Herbivorous ungulates are preys suitable for trapping by means of a system of kites. They occur in groups and/or herds and some of them protect themselves by regrouping 
in defensive formations. For example, gazelles were once very common in steppe and arid areas and accounted for the most favorable candidates for kite-type trap systems. Observations on gazelle behaviour (Gazella gazella and Gazella dorcas) revealed that these herbivores tend to run parallel to low walls/fences and thus can be easily directed by antennae of kites toward the trapping enclosure (Holzer et al. 2010). In the case of goitered gazelle, (Gazella subguttorosa), corresponding data is lacking, but it is known that under stress or in danger, these gazelles react instinctively by escaping in a closely packed formation and run in a straight course, backward or forward, in front of the pursuer (Kingswood and Blank 1996). Gazelles in general migrate seasonally according to the availability of forage (Harrison 1968; Martin 2000a). They are gregarious and occur in small groups. But, in the case of goitered gazelle, they migrate in herds numbering in the hundreds or thousands. Group structures change between the warm and hot season. Three configurations can occur: female adults with juveniles, solitary male adults and sub-adult males (Kingswood and Blank 1996).

Unfortunately, little is known about the exploitation of trapped animals within the kites immediately after hunting. The only evidence was generated from the ethnographical observation of Bedouin societies and from accounts of travelers who have either seen or heard about kite use in Syria and Jordan.

Archaeozoological data clearly reveals that bone remains of wild ungulates such as gazelles, aurochs, ibex, equids and cervids were the principal game hunted. They occurred from the Paleolithic times in the Levant, northern Syria, Mesopotamia and Transcaucasia. In Arabia, equids, antelopes and camelids were the main culled species. During the Neolithic, along with the domestication of sheep, goats, cattle and pigs, hunting practices still evolved and continued to focus on the same species found in the vicinity, but tended to gradually decrease in importance with time (Davis 1982; Vila 1991; Bar-Oz 2004; Helmer et al. 2004; Gourichon 2004; Gourichon et al. 2006; Uerpmann 2008; Sapir-Hen et al. 2009; Martin 1998; Martin et al. 2009; Tsahar et al. 2009; Bălășescu et al. 2010; Chahoud and Vila 2011).

Hunted game was either trapped alive (Musil 1928; Jabbur and Conrad 1995: 288; Fowden 1999) or mass slaughtered, and the entire game carcasses or body parts were carried away (Sergeant 1976; Baroin 2006). However, remainders of meat processing including discarded material, evidence of butchery, and meat conservation are not apparent in the archaeozoological record. Scarce archaeological data reveal mass kill spectrum or settlements specialized in carcass treatment at sites close to the kites. Recent studies on the Khabur region have revealed one butchering site (Kuran, mid 4th millennium BC) with remains of carcass disarticulation (bones of gazelle feet). This Northern Syrian site is located near the Hemma kites group (Zeder et al. 2013).

\section{The Husbandry Model}

The pastoralism model suggests the use by transhumant societies of kites as enclosures for gathering domesticated animals. Some authors have interpreted the scenes of trapped animals in rock engravings as livestock management (Rees 1929; Échallier and Braemer 1995; Jabbur and Conrad 1995).

In the Middle East, pastoralism and transhumance were the dominant economic practices until the last century (Bar-Yosef and Belfer-Cohen 1989; Mashkour and Vila 2003; Ur and Hammer 2009). This region is a natural distribution zone for four 
domestic ungulates highly exploited from the Neolithic period onwards: sheep, goat, cattle and pig. The breeding pattern, based mainly on ovicaprine transhumance, implies the annual migration of pastoral populations with their flocks. This indicates the need for seasonal camps to protect the animals in isolated fragile environments, as well as enclosures for concentrating livestock - the rounding-up of the latter for inspection or other purposes (D’Hont 1994). Kite structures could reflect this use, hence the interpretation of kites as structures related to livestock rearing.

Current research dates the domestication process of these ungulates back to the 8th millennium BC (Helmer et al. 1998). The main source of animal protein, previously based on wild game meat, was replaced during the Neolithic by livestock and dairy products. Domesticated animals became the daily basis of diet and the centre of the economy of Neolithic and Bronze Age societies, according to animal remains attested on most archaeological sites (Grigson 1987, 2006; Vila 1998, 2006; Martin 2000b; Horwitz et al. 2001, 2002; Peters et al. 2005). In archaeozoological records, caprines dominate faunal assemblages in the Near East, Arabia and Transcaucasia since the Neolithic period (Vila 1998, 2006; Martin 2000b; Horwitz et al. 2001, 2002; Grigson 2006; Bălăşescu et al. 2010; Vila and Helmer 2014). It is possible to state that the economy was based on husbandry and not hunting activities based on archaeozoological data from Bronze Age sites in Syria, taken from a concentration of several hundred kites (e.g. Khirbet al-Umbashi (Southern Syria): Vila 2004; Al-Rawda (Steppe, east of Hama): Vila and Al Besso 2014). If it is posited that kites were used for hunting gazelles, it should expected that there is a significant frequency of wild game bone in the assemblages. Consequently, if a direct relationship exists between kites and settlement, the question arises of whether kites were already in existence, but not used during the Early Bronze Age of this area or whether they were subsequently built. Alternatively, one can assume kites were used by the inhabitants of the region for the management of livestock.

\section{Archaeozoological Analyses}

In order to identify the function of kites, a complete analysis of faunal remains from archaeological sites needs to be carried out in order to correlate kite and faunal distribution. The study of the function of kites is considered in close connection with an investigation on animal resources and human subsistence strategies. Hunting and/or pastoralism models using kites imply a need for the gathering of large numbers of animals, choices in consumption and an exploitation of animal products. Analysis of the animal remains whether either slaughtered games or livestock, mortality profiles, body part selection, provides valuable insights into both the human use of animals in the past, as well as probably on the methods of acquiring these resources, whether related to kites or not.

So far, no global analyses of archaeozoological records have taken into account the variability and distribution of kites in relation to the availability of animal resources, their procurement and their consumption. This should be done in order to examine the correlation between kites as massive traps/enclosures and the demands of ancient societies. Furthermore, there does not appear to be a direct relation between the consumed wild game found on settlement sites and hunting and capture zones. By integrating structure, geographic location and function of kites and correlating these 
with animal occurrence (current and historical) and bone assemblages in the areas of kites (Middle East, Arabia and the Caucasus), it would be possible to establish several functional patterns. These patterns could be used to test the validity of each model in order to suggest a possible connection with kites. If the ecology and behaviour of animals were considered as vectors, it would be possible to examine the consistency of hunting and/or pastoral uses in conjunction with the regional management of animal resources.

Several analyses were carried out with this aim in mind: (a) the study of animal remains from the excavation of kites; (b) the recording and mapping of current and ancient distribution of species. This project focused on the ungulates; (c) the creation and filling of a database of archaeozoological analyses which include regional and chronological features of sites. The main issue is to homogenize the dataset from different publications and current studies to be able to analyze and compare ancient animal distribution, the animal-based economy and the evolution of wild game or livestock dependency during the Holocene. (d) Analyses of the ecology and ethology of animals likely to be trapped by kites. For instance: the classification of gazelles remains complex despite recent phylogenetic analyses (Bärmann et al. 2013; Lerp et al. 2013). Nevertheless, three main species of gazelles in the Middle East can be distinguished (Harrison 1968): mountain gazelle (G. gazella), dorcas (G. dorcas) and the goitered or Persian gazelle ( $G$. subgutturosa). Mountain gazelles are endemic to coastal regions and mountain ranges of the Levant and the Arabian Peninsula. The dorcas gazelle is a subspecies in the southern Levant, Sahara and East Africa. The goitered gazelle is widespread in the Near and Middle East and in an area spanning from the Arabian Peninsula to south Mongolia and the Caucasus (Kingswood and Blank 1996). This gazelle subspecies lives in desert and semiarid biotopes of all types. (e) Ethnographical study must be conducted to explore different forms of pastoralism according to available studies, to make observations relevant to current livestock management and transhumance practices and by examining hunting techniques. These ethnographical records can serve as a benchmark for the study of the function of kites.

Three patterns should be cross-examined according to period and region for a global approach on the management and use of animal resources, using theses analyses: archaeozoological data, animal occurrence and behaviour and ethnographical studies. Cross-matching these patterns in this larger framework with other aspects of kites in the Globalkites project could enable a better understanding of the function of kites and their possible relevance to a cultural timeline. It would then be possible to examine the viability of the three-tiered system relating trap-hunters and prey, on the one hand, and/ or enclosure-shepherd and flock and the kites themselves, on the other. In other words, throughout these archaeozoological, ethological and ethnographic analyses, a feasibility study is proposed of: animal occurrence, mobility and role in ancient society, activities of the hunters/pastoralists who might have built and used the kites, their need for such trapping system and the benefits of these structures.

\section{Environmental Perspectives}

The environmental contexts of the kites are periodically mentioned and described in the literature and authors generally agree on the fact that the location of kites in the 
landscape reflects choices, most often recurrent. These were guided by a profound knowledge of the environment and of the biotic communities that constitute it, and by a special awareness of faunal behaviour. This Traditional Ecological Knowledge (Berkes 2008: 7) is, according to B.D. Smith (2013: 10), a fundamental aspect of societies who used structures such as large-scale traps. Several criteria have been suggested for the establishment of kites based specifically on traditional ecological knowledge.

\section{Review of the Criteria Relevant to the Choice of Location for Kites}

The proposals that explain the choice of locations exclusively emphasize the links between environmental characteristics and the behaviour of wild fauna. The criterion most frequently mentioned for the choice of kite construction is the search for food, and less importantly for water as these were guided by daily and seasonal cycles. Many authors posit the view that kites were constructed and oriented at the regional scale in relation to faunal migration routes (Helms and Betts 1987; Perevolotsky and Baharav 1991; Betts 1998; Betts and Yagodin 2000; Deom and Sala 2009; Morandi Bonacossi and Iamoni 2012; Kempe and Al-Malabeh 2013; Brochier et al. 2014). While at the local level, their construction is connected to daily itineraries as well as to the availability of pasture zones and water holes (Helms and Betts 1987; Perevolotsky and Baharav 1991; Betts and Yagodin 2000; Holzer et al. 2010; Nadel et al. 2013). Topography is the second criterion most commonly suggested (Helms and Betts 1987; Betts and Yagodin 2000; Holzer et al. 2010; Morandi Bonacossi and Iamoni 2012; Nadel et al. 2013; Quenet and Chambrade 2013; Brochier et al. 2014), i.e. essentially the taking advantage of a change of slope hiding the enclosure until the animals either approach or enter it and therefore either preventing or substantially curtailing any likelihood of flight. It was concluded that the direction of either the sun or the prevailing winds was less important in the choice of location for kites (Échallier and Braemer 1995; Nadel et al. 2013).

These hypotheses are inspired or comforted by ethnographical observations carried out on European or North American large-scale traps (e.g. Ingold 1980; Arkush 1986; Gordon 1990). Nevertheless, the basis of some of these hypotheses was questioned despite the recurrence of patterns for kite location (Échallier and Braemer 1995). It can be argued that the study of environmental contexts and their relationship to kites has not until now been the focus of neither a systematic and comprehensive approach, nor of a comparative study at a scale that covers their area of distribution.

\section{A New Systematic and Global Approach for the Environment of Kites}

The study of the environment of kites is designed to determine the role of environmental conditions in the construction of structures dedicated to subsistence activities. The analysis of resources and environmental constraints enables researchers to understand how and why these activities were carried out. The Globalkites project addresses these environment studies by means of three spatial analyses. At the micro-regional scale, the reconstruction of the kites in their natural context aims to understand choices for the location of kites and explaining their use(s) and the way(s) they operated. At the regional level, this means a study of the environmental zone which was inhabited by the human groups who used the kites. A comparison of data at the macro-regional scale 
will enable both the similarities and the discrepancies in the choices of where kites were placed as well as the exploitation strategies of kites according to environmental zones to be grasped. The environment is tackled through three aspects that were researched: climate, natural resources and topography. Furthermore, owing to the relationship between environment, animal presence and kites' location, environmental studies and archaeozoological analysis are carried out in closely interrelated manner.

\section{Climate}

The Near East has a Mediterranean climatic regime, with rainy winter and dry summers. This has been the case for approximately 17,000 years (Issar and Zohar 2007: 53). The climate is characterized by a substantial decrease of rainfall from the West to the Southeast. In the current state of knowledge, kites are restricted to semi-arid to desert bio-climatic zones, which means they are found where annual rainfall ranges from 100 to $600 \mathrm{~mm}$. Kites are generally absent from the most humid zones and in certain cases from the driest regions. This specificity needs to be explored in detail, and it is important to establish if the reasons for such distribution are preferentially human and/or environmental. The succession of climatic oscillations during the Holocene had a greater or weaker impact depending on periods and regions (Migowski et al. 2006; Robinson et al. 2006; Verheyden et al. 2008; Develle et al. 2011). This climatic stress possibly had an influence on the development and abandonment of kites, especially when these were used over a quite short time span.

Climatic aridity and seasonality are causes for constraints on vegetation and fauna, as well as on human settlement. These constraints can lead to a number of adaptations, especially those affecting lifestyles and subsistence and the development of socioeconomic and technical innovations (e.g. pastoral nomadism, hydraulic installations). Were kites one of the forms of adaptation to these constraints and were they used year-round, or during one or several seasons in particular? As widely observed, climatic seasonality in part influences the subsistence activity cycle, particularly guided by the differential distribution in space and time of the quantity and quality of potential resources (Monks 1981). The hypothesis of an establishment of kites in relation to faunal seasonal migrations will be explored further, as will be the issue of seasons during which the kites would have provided the best returns.

\section{Natural resources}

Climatic characteristics of arid zones are the reason for the predominantly low and open natural vegetation, at times concentrated in certain micro-catchments and microenvironments more favorable to its development. They are also the cause of a temporary access to surface water in large areas. Échallier and Braemer $(1995: 50,60)$ are not convinced of the potential link between the vegetation and the hydrographic network and the kites themselves. However, vegetation distribution redirects faunal daily itineraries and could have therefore influenced the implantation of kites. Furthermore, access to drinking water remains an important element to be taken into account. The authors mention the recurrent location of southern Syrian kites at the margins of zones where water was found at certain times of the year. 
Moreover, Burckhardt (1831: 220) observed gazelle hunts carried out with devices akin to the kites in concept, noted that enclosures were located close to water holes and sources, since these attracted gazelles in the summer. Water and natural vegetation are therefore studied in a seasonal perspective, i.e. the differential distribution and availability during the year of these two resources. The presence of water resources would have provided reasons important enough for the selection of specific locations for kites. Some animals are 'obligate drinkers', i.e. they need regular access to a water resource. This need becomes critical during the dry season. For other species, pasture grounds suffice to ensure water requirements, some animals even practicing a mixed strategy (Speth 2013: 179). The natural resources including vegetation and water and the faunal distribution from the Holocene period, based on archaeozoological analyses of the Globalkites project, are currently being mapped together.

\section{Topography}

An observation of relief and terrain, understood from the features that it comprises (e.g. plateaus, mountain ranges), enables researchers to outline diversified catchments. Some initial preliminary observations can be put forward based on spatially orientated inventory of kites.

Those kites at the highest elevations are located in Armenia, since their altitudes are approximately 1,500 $\mathrm{m}$ above sea level (asl). Apart from those in Armenia, elevations above 1,500 m concern only restricted zones within the distribution area of the Near Eastern kites: the Anti-Lebanon/Hermon ranges and the central Jabal al-'Arab in Syria, and some very localized sectors in southwestern Jordan and northwestern Arabia, as well as in the southwest of the Arabian Peninsula. Apart from those kites in Armenia, only $7 \%$ of kites are located at an elevation above $1,000 \mathrm{~m}$ asl. These are in Syria on the eastern slopes of the Jabal al-'Arab, Southern Palmyrena ranges and north of the Anti-Lebanon. The norm is a location of kites at between 500 and 1,000 m asl (70\%), with two thirds of the kites found between 500 and $750 \mathrm{~m}$. This upper limit in elevation $(1,500 \mathrm{~m})$, therefore, does not seem to be a sufficiently relevant datum, and in any case cannot be compared at the macro-regional level. Yet on a regional scale, elevation must be confronted to wild fauna occurrence in higher mountains, as well as to vegetation.

One observes primarily, at the macro-regional scale, that kites are absent from plains, endoreic depressions typical of arid areas and from the core of mountainous sectors. They are, in contrast, preferentially implanted on the latter's foothills and the piedmont, as well as on plateaus (most often of basalt). Were kites effectively associated with these environments in particular? For what reasons and why are they absent from certain types of environments? An answer to these questions lies in the confrontation of data related to the environment and to that relevant to subsistence activities.

At a finer scale, the systematic analysis of the positioning of kites and of their various elements, in relation to local topography and components of the landscape, greatly contributes to the study of the kites' inner workings. It was often observed that the existence of a change in slope hid the enclosure from the corridor formed by the antennae. New recurrent elements should be identified. This concerns for instance the position of the cells in relation to the enclosure, sometimes also hidden by a change in slope (as observed in Jordan). Another element could also for example be the existence of a corridor, such as a river or streambed, 
which would have enabled the easy redirection of the animals towards the kite (see Arkush 1986 on the hunting of pronghorns).

The analysis of environmental contexts consequently yields an overview on potential and the constraints linked to animal capture zones and environments. It also clarifies the relative difficulties in the selection of geographic location of kites and issues of human subsistence. Therefore Geographic Information System (GIS) is essential in order to observe kites from a global perspective.

\section{GIS as a Critical Tool for a Geographical Understanding of the Kites Phenomenon}

In terms of all the archaeological issues related to the kites, one the most important is their geographical dimension. More precisely, the spatial component is intertwined with most issues posited by these installations - distribution of animal species, layout and arrangement of environmental settings, control and territorial layout, economic networks, diffusion phenomena, etc... The spatial component is related to the ecosystem which is that it is to the anthropo-systemic sphere. The approach therefore derives from general geography, both human and environmental. The question of scale is also ever-present, from the macro-regional scale to that of the architectural element.

The use of GIS becomes from then on unavoidable: the variety and quantity of data and their spatial and multi-scalar character in themselves justify its use for the recording and consultation of inventories. Representational functionalities ensure moreover being able to face the (in principle recurrent) need for mapping documentation. The anticipated use of GIS also is due to the very functions of analysis, and these are suitable to make the tool heuristic since it allows the cross-matching of data, distributional analysis, analysis of distances and geo-statistics.

\section{Inventories}

The study of kites at the scale of their area of distribution presupposes an inventory which is as comprehensive as possible. Indeed, the information source which shows the greatest homogeneous character consists of high-resolution satellite imagery. The images at the public's disposal, provided by Google Earth and Microsoft Bing, are complementary in that they give an almost complete and comprehensive high resolution coverage. The inventory partly derived from recent publications on kites (Kempe and Al-Malabeh 2013; Kennedy 2012; Morandi et al. 2012), was completed by meticulous and detailed research and today has reached a figure of more than 4,300 items (Barge et al. 2013). The precise geographical location of these kites is the GIS's first feature class. It includes a feature attribute table with some twenty fields which allows information to be stored on size (length of antennae, enclosure surface...) as well as and information on figures, numbers, counts or on the presence of architectural elements (number of small cells, position of the latter, presence of a funnel-shaped entrance...) This information is being entered digitally. If the detailed information required on the totality of kites in the inventory is too long and too painstaking a process, a meaningful sample could allow numerous analyses (see below). At this 
general scale, environmental and zoological data are also in the process of being incorporated. The set of these data are gathered in a spatial database, which moreover includes a Digital Elevation Model (DEM).

It is at either the regional or micro-regional scale that one can best grasp the issues relating on the one hand to kite implantations in a given environmental setting and territorial structuration, and on the other to the functioning of kites. To this end, 'windows' were established while taking into account both the kite distribution and data availability (from fieldwork or if this was lacking from bibliography). A spatial regional database, which was interfaced with the general spatial database, corresponded to each window. One of these windows concerns the region of the Aragats in Armenia, where three fieldworks have already taken place. Jointly to the punctual implantation of kites, one finds a feature class of archaeological sites. Kites and their constitutive elements are described in a feature dataset, which includes a feature class called 'walls'. Within it, these 'walls' of kites were digitally recorded either from high-resolution imagery or from a ground plan in the field (drawn with a Trimble Differential GPS).

In this case, the attribute fields enable the description of the construction technique (simple or double facing), and the height and width of walls in homogeneous sections. This feature dataset also includes specific feature classes meant to describe the small cells (types, dimensions), subdivisions, as well as the eventual presence of other elements (for instance tombs). It also comprises feature classes meant to record work in the field (soundings, profiles and sections, field samples). Kites which were studied were also the focus of aerial photography using a kite. Photogrammetry from this pictures enables to obtain ortho-photographs and DEM at a very refined scale (Fig. 4). This set of documents is stored in a spatial database, which coincides with the regional window.

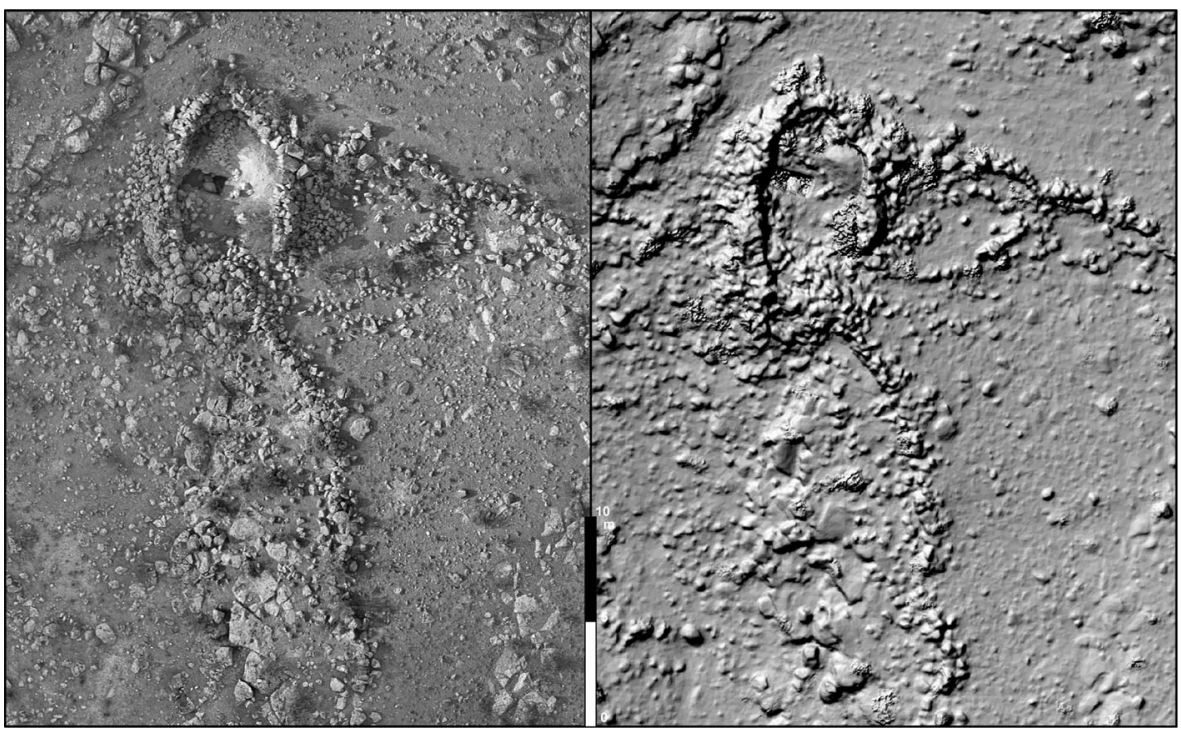

Fig. 4 Cell L14-01, example of ortho-photography (to the left) and of hilshade derived from a DEM (to the right) produced by photogammetry and stored in the spatial database 


\section{Mapping}

Mapping is a source of documentation which is of prime importance when dealing with the issue of kites. The functionalities of automatic representation, just like those of publishing, are subsequently applied. The scale of documents produced can be very variable, from general distribution area to architectural components of a kite. For greater scales, Mercator transverse projections are used, with a UTM strip coinciding with the relevant zone. For small scales, a conical Lambert consistent projection concentrated on the distribution area of kites to be defined.

Simple distribution maps can therefore be drawn (Fig. 1). In particular, it is quite relevant to separately map the different descriptors obtained from satellite imagery. This enables researchers to pinpoint if elements of size or presence of certain architectural attributes show a particular form in terms of spatial distribution. Figure 5 for instance shows that the length of antennae is a rather important criterion in isolated kites (Fig. 5a) or whether the orientation of kites conforms to that of slopes (Fig. 5c). This example taken from Armenia nevertheless possesses limited significance in that this region shows quite consistent morphological unity. Undoubtedly, these maps will enlighten clearer differences when they will be redrawn and published at a regional scale, and they will be very useful in discerning regional peculiarities.

Maps at more refined scales are interesting in that they reveal the insertion of kites into the environment and expose their architecture. It is at this scale that the functioning of kites or sets of kites can be grasped. Figure 6 shows the alignment of kites and their position in relation to the edge of the volcanic flow. Here the antennae point uphill and encircle the rim of the plateau which is of low inclination and enclosures on the slope of the flow's edge and entrance where the slope changes. The plans of kites reveal their architecture, the eventual specificities or superimpositions. Kite 67 (Fig. 7), for example, is probably later than a more ancient kite since it is only a pointed cell survives (to the north-east), while its enclosure wall was destroyed to the west by medieval occupation. Finally, these documents also help in locating where fieldwork has been carried out (Fig. 8).

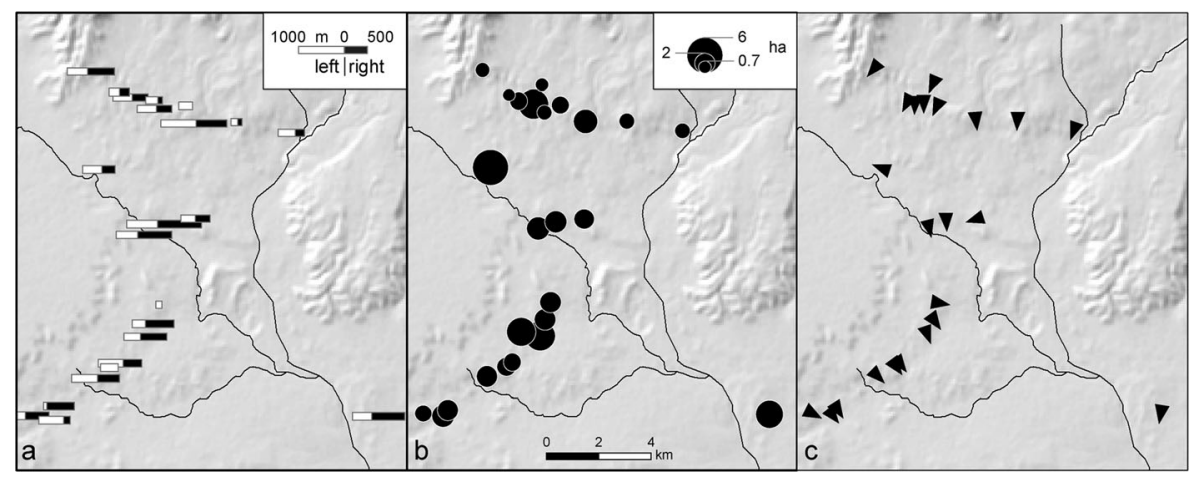

Fig. 5 Examples of theme-based mapping: a length of antennae, $\mathbf{b}$ surfaces of enclosures in hectares, and $\mathbf{c}$ direction of opening 


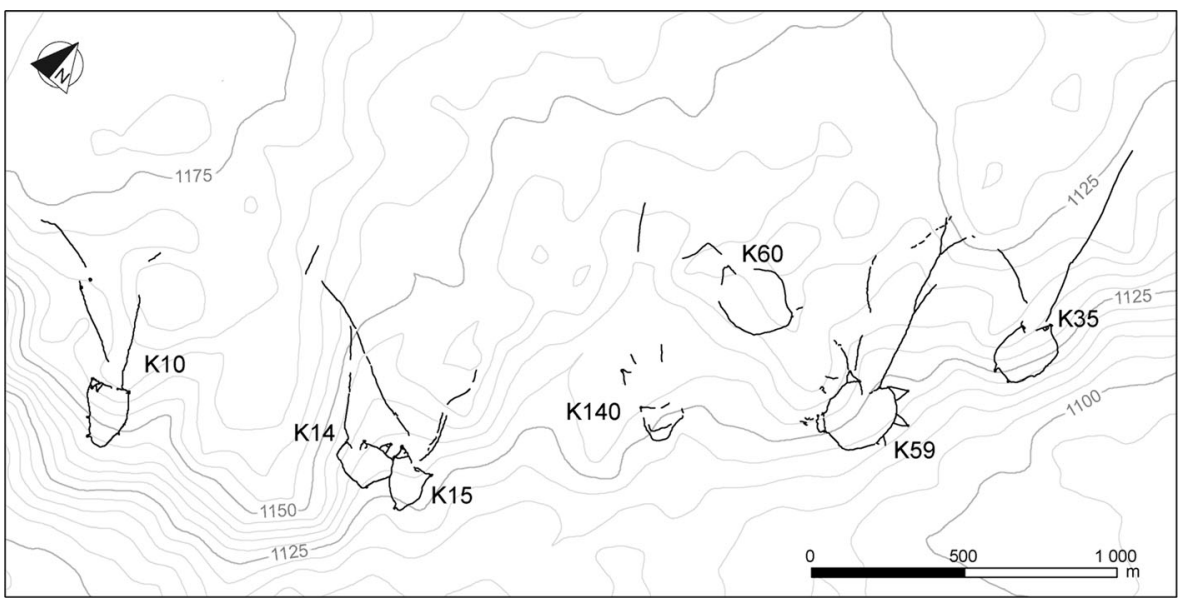

Fig. 6 The Aragats kites (Armenia) at the scale of a single slope

Modes and Methods of Analysis

In many ways, it is difficult to select the most efficient types of analysis, since possibilities offered by the GIS are so varied. The possibilities include: spatial crossmatching of information, closest neighbor analysis, analyses of distances, distributions and the combinations of descriptors (Rodier et al. 2011). The orientation of GIS research relies heavily on information that both previously gathered and to be collected in the future.

However, several approaches can already be imagined because they were tested in Armenia. Statistical analysis and a geo-statistic examination of details (from satellite imagery) make scholars expect interesting results. Multiple correspondence analyses are aimed at revealing original combinations that are recurrent. What is projected is to identify in more secure fashion the regional specificities that are perceived in a rather more obscure and empirical manner, and subsequently seek to interpret these results. These specificities can be rendered discrete and eventually explained eventually by functional, chronological and environmental factors. Conducted in Armenia, this research has enabled emphasizing the morphologically homogeneous character of this sub-set. It has also permitted the allotment of a distinct function from that of kites to a set of installations which, without possessing of all attributes of kites, do present some of their salient features.

Cross-matching certain characteristics of kites with environmental parameters can also yield interesting functional clues. In Armenia for instance, the link between the direction of the opening of kites and the orientation of slopes was proven (Barge and Brochier 2011). The direction of the opening of kites is in effect an interesting element of data that some associate with the hunting of migrating animals (Morandi Bonacossi and Iamoni 2012). However, it seems quite awkward to state this in the absence of reliable data on migrations on the one hand, and given the unavailability of regional comparisons for the direction of openings on the other. In Armenia, given the general orientation of slopes towards the east and southwest, it is difficult to determine with precision the part played by gradients and slopes. Consequently preferential orientations could not either be confirmed or disproven. At the level of the entire set of kites, 


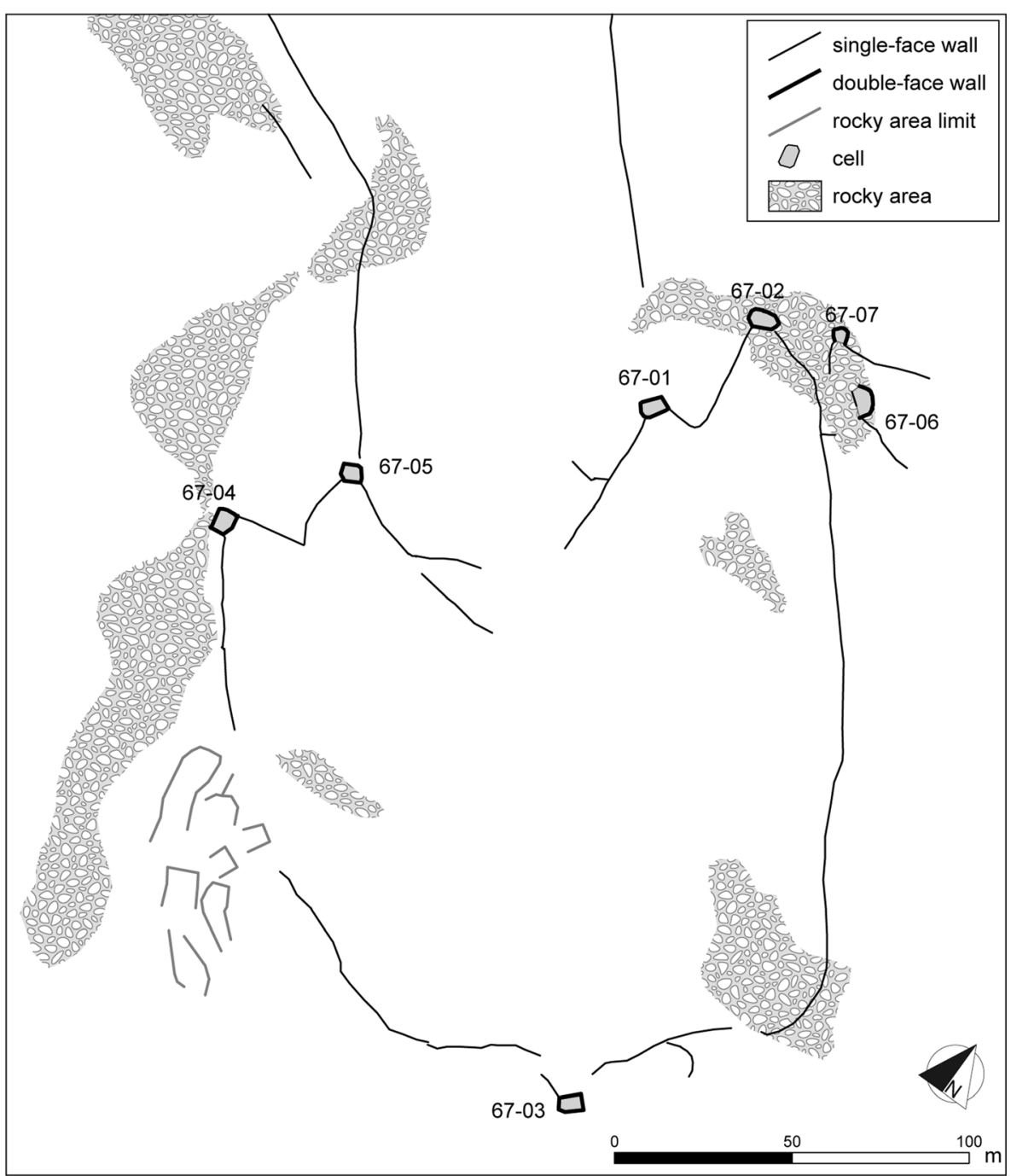

Fig. 7 Example of a kite plan: Kite 67 drawn with a Trimble DGPS

these analyses will undoubtedly provide relevant clues because topographical contexts often stand in greater contrast and the directions of openings become more clearly apparent.

At the same scale, but with less certainty because the necessary data remains unavailable, it was planned to search for regularities in the relationship between environmental data and the location of kites. One can in fact observe that kites are located both in zones marked by aridity, in sectors void of any tree cover and places with a marked topography. These cross-matches should entail confirmation of this fact and yield more precise details on the matter. This type of cross-matching should also be conducted on the archaeozoological data. In particular, localized data on fauna from different periods at archaeological sites could be compared to kite distribution and 


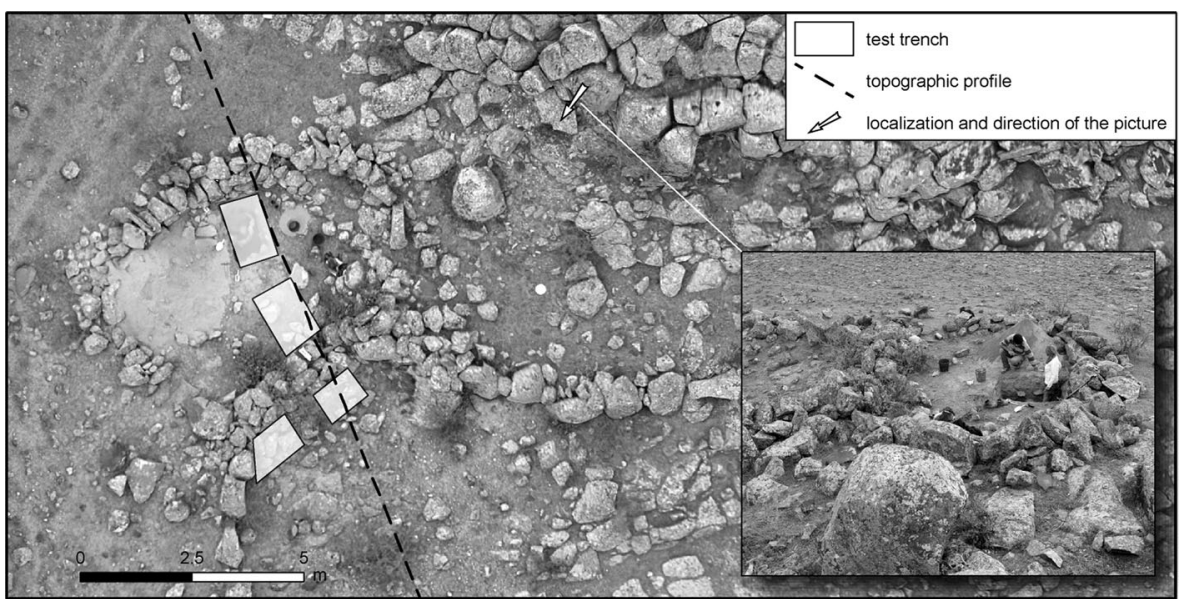

Fig. 8 Cell L14-01 (Aragats, Armenia): localization of fieldwork (topographical profile, soundings) and photographs at ground level

could provide answers on the species concerned by these huge trapping devices. In the cases where the available data does allow this, the relationship between kites and settlement patterns of a given territory (sedentary, nomadic) can on the one hand be assessed, and settlement dynamics examined. Such analysis can be undertaken by carrying out analyses of relative distances between archaeological sites (occupied at different periods) and the kites themselves. Finally, but on a more experimental level, the functions of complex distances that include directions of displacement (supposed migrations) and the roughness of terrain (geographical constraints) should be called upon to attempt to create a model of animal displacement, the aim being to test functional hypotheses.

\section{Geoarchaeology and Chronometry: Two Complementary Approaches}

An unavoidable prerequisite of any archaeological discourse is the dating which is both relative and absolute. This problem remains despite a century after initial discovery particularly difficult to tackle. Of the thousands of kites known in the Near East, very few have been excavated and even fewer subjected to chronological analysis. The most numerous and the most reliable data come from kites in the Sinai and the Negev (the analyses concern five of the seventeen known kites) where the constructions were used between the end of the fourth and the third millennium BC (Kobusiewicz 1999; Holzer et al. 2010; Nadel et al. 2010). But these dates only provide information only on the chronology of kites that are very particular morphologically and outside the SyroJordanian region, where they are both much more numerous and varied. Elsewhere, chronological indications are rare and rather unclear. In any case, they do not allow one to assess whether the kites were used over millennia from the very beginning of the Neolithic either beforehand, or only during one or several brief periods. However it appears that the end of the fourth and the third millennium were the main periods of use (Échallier and Braemer 1995). The great morphological diversity observed in both Jordan and Syria (Helms and Betts 1987; Échallier and Braemer 1995), the frequent 
modification in plan and of course the accounts of usage in the modern period argue that kites were used over a long time frame.

Two complementary chronological approaches have been developed in the framework of the Globalkites project: geoarchaeological analysis which rests essentially on the analysis of anthropogenic dust and absolute chronological measurements.

\section{Anthropogenic Dust and Relative Chronology}

The kite cells, which are generally deep, are the places where sediment, both windblown and/or from runoff, have most commonly accumulated since abandonment of the constructions. Consequently, they preserve the traces of a long history of visits by men, by their livestock or by wild animals. The method, developed during the study of the Syrian steppe's pastoral enclosures (Brochier 2014), was successfully transposed to the case of the Aragats kites in Armenia. Without entering into the arcane intricacies of a complex methodology, something already detailed by Brochier et al. (2014), the Armenian example has brought to light the fact that since their abandonment the cells were filled by detrital sediment mixed with biogenic remains originating from domesticated and/or wild ruminants visiting the kite and its immediate surroundings. What was in fact observed was the presence of carbonated faecal spherulites, siliceous phytoliths (although part of them no doubt were the result of natural decay of local vegetation) and above all numerous remains of silicified unicellular algae very classically associated with ruminants' faeces (Brochier2002). Settlements, characterized mainly by wood ash (calcitic pseudomorphs after calcium oxalate, or POCC; Brochier and Thinon 2003) are, in all cases, extremely hard to identify. Following pioneering works by Smol (1985), one has become aware of the balance between diatom frustules and chrysophycean statospores during the course of time, as a function of anthropogenic disturbance which was the reason for the catchment's eutrophisation. It is this very feature that allows us to follow anthropogenic disturbances in a given geographical sector, to measure their impact and, by comparison with spectra obtained in dated rural settlements, to order the different stratigraphic sequences observed. The example of the Aragats (Fig. 9) demonstrates that the studied kites are considerably earlier in age than the Middle Ages. This fact is confirmed by some rare cases of superimposition which is a particularity that has been discussed elsewhere (Helms and Betts 1987: 50; Échallier and Braemer 1995: 54; Zeder et al. 2013: 115). They additionally enable one to proceed to a screening of samples for radiocarbon analysis.

\section{Absolute Chronology}

Apart from exceptional examples from the Negev and Sinai, the absolute dating of these constructions is a particularly difficult task. In the framework of the Globalkites project, two methods seem in our opinion to be applicable in many cases: the measurement of residual radiocarbon and Optically Stimulated Luminescence (OSL). In some geological contexts and specific environments such as the case of the Aragats the uranium-thorium (U/Th) method applied to carbonated crusts also appears to be able to provide results.

During excavation carried out in the cells of the kites, it was rare to encounter either wood charcoal or carbonized seeds, and finding them deep down in stratigraphic layers 


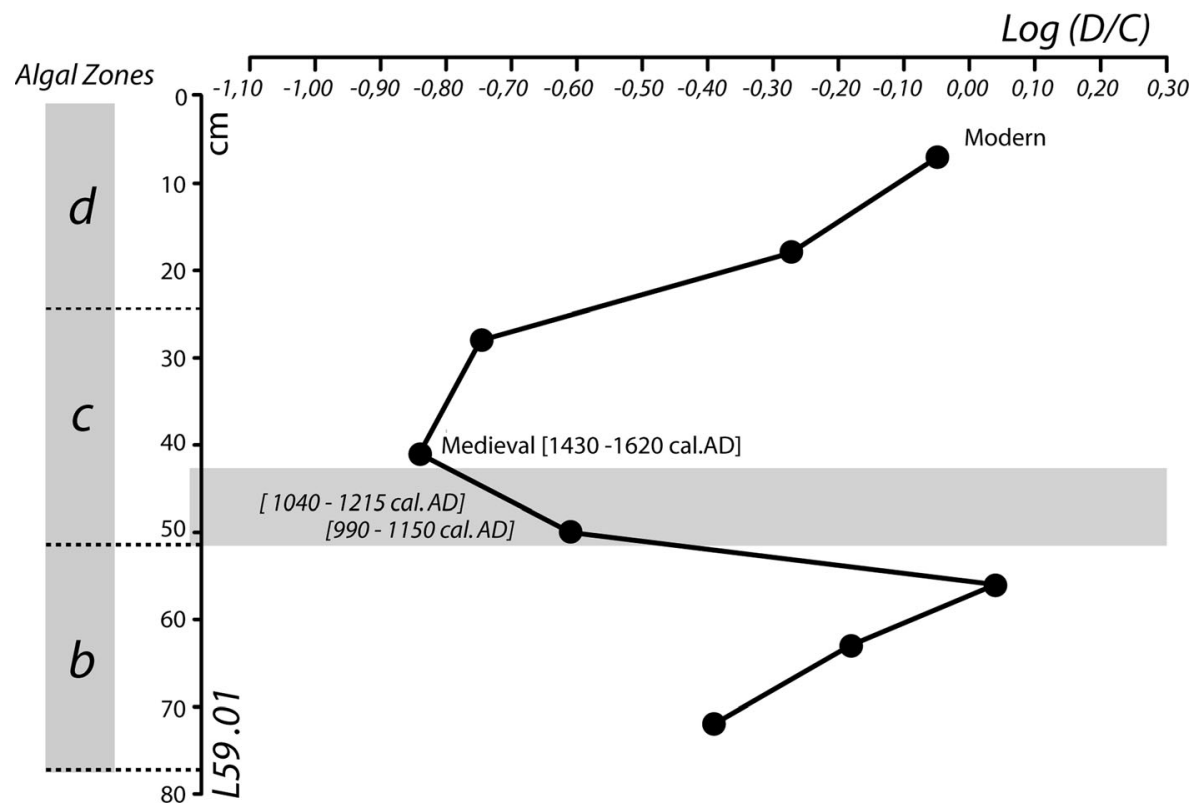

Fig. 9 L59.01 cell. Examples of the evolution of relative proportions of diatom frustules to chrysophycaean statospores; the horizontal grey stripe marks the position of a level yielding some bone splinters. Absolute chronological benchmarks in italics; in normal fonts dates estimated by comparison with the spectra of known periods. Note modern (and present day) eutrophisation of humid zones

was an even scarcer occurrence. The procedure that routinely applied consists in sampling, washing on a fine mesh $(0.5 \mathrm{~mm})$ and sorting out under a binocular magnifying glass the residue from several kilograms of sediment sample extracted from the soil, while bearing in mind the stratigraphy. Experience demonstrated that carbonated material, both in Armenia and Kazakhstan, despite being not very abundant, is often present in sufficient quantities to be analyzed through modern AMS techniques. One should in particular emphasize the frequent occurrence in these fills of two types of biogenic carbonates potentially yielding reliable results: millimeter-large fragments of bird eggshell and limestone seeds of Boraginaceae of the Lithospermum genus. Indeed the ability to gather the tens of milligrams necessary to produce a date is possible. The presence of charcoal and of bone splinters is much more random. This type of research, though necessary, nevertheless in all cases only provides researchers with a terminus ante quem. The greatest difficulty resides in the determination of a terminus post quem. The problem can only be solved on a case-by-case basis, depending on geological, stratigraphic and architectural contexts, by calling upon radiocarbon analyses, OSL or $\mathrm{U} / \mathrm{Th}$.

\section{A Mathematical and IT Processing Approach to Kite Recognition}

An important aspect of the project is the development of a pattern recognition tool that will be based on the specific shapes and sizes of kites. This tool will allow a comprehensive inventory of these structures worldwide. The systematic identification 
of kites on satellite images from Google Earth enables to delimit this phenomenon from a spatial viewpoint. It also allows a determination of other hunting or pastoral developments that are analogous to kites but must be culturally excluded.

The identification of objects in images is a fundamental scientific issue in many fields and industrial applications. Indeed, the recognition of objects and shapes in images is one of the most difficult problems of computer vision. In fact, the same object can seem completely different depending on the standpoint, the scale, the lighting, quality of images and many other factors such as partial occlusion and background add-on. Applied to the analysis of satellite images of Google Earth-type, we will process the images in order to minimize these drawbacks, especially lighting, color changes and background add-on.

We can classify object recognition methods into four main approaches (van de Sande et al. 2010): geometry and matching, sliding windows, deformable models, and feature extraction and classification. The latter approach currently gives the best results regardless of the type of objects. However, the other approaches may be particularly effective according to the context. In particular, when the desired object has a structured form, which is the case of kites, the geometry and matching approaches are particularly interesting. We propose in this study to go beyond the traditional boundaries of geometry-matching and feature extraction-classification approaches and combine the advantages of both approaches in a new model for object detection based on a graph modeling of images. A graph is a modeling tool composed of a set of vertices and a set of edges that connect the vertices.

Graphs are frequently used in image recognition. The main advantage of using graphs for the representation of images is the integration of spatial information in the representation. Indeed, conventional representations such as color histograms, texture descriptors, etc. provide no information on how the regions of interest of the image are arranged. The graph representation allows us to describe the structure of the image, i.e., how the parts are arranged relatively to each other. Moreover, according to the chosen types of relationships, this graph representation (Fig. 10) can be invariant under certain transformations such as rotations of the image or translations of parts of the image.

Graph theory is a powerful tool for studying complex combinatorial structures. Among the major research topics in the field that develop methods for the design and manipulation of complex structures, we can cite: graph embedding, graph decomposition and partitioning and graph Kernels (Haussler 1999; Dong et al. 2008; Bunke and Riesen 2011; Lagraa et al. 2014). Graph kernels construct the similarity between complex objects using the similarity of parts of these objects (Haussler 1999; Gärtner et al. 2003). The basic idea is that it is easier to design a similarity function between small parts than similarity function between objects made of these parts. To do so, graph decomposition and partitioning are important issues. Graph embedding generally aims to represent the graph structure by a vector, for example by computing its distance to a set of graph prototypes (Emms et al. 2007).

The problem of kite recognition using graphs can be viewed as a set of steps as follows; Step 1 is characterized by modeling a kite by a graph and constructing a set of graph prototypes for kites. An initial model for kite recognition is established, based on archaeological and geographical knowledge. This model will be gradually improved with the feedback of archaeologists and geographers (experts on the results provided by the model). During Step 2, the following tasks are realized for each processed image: 

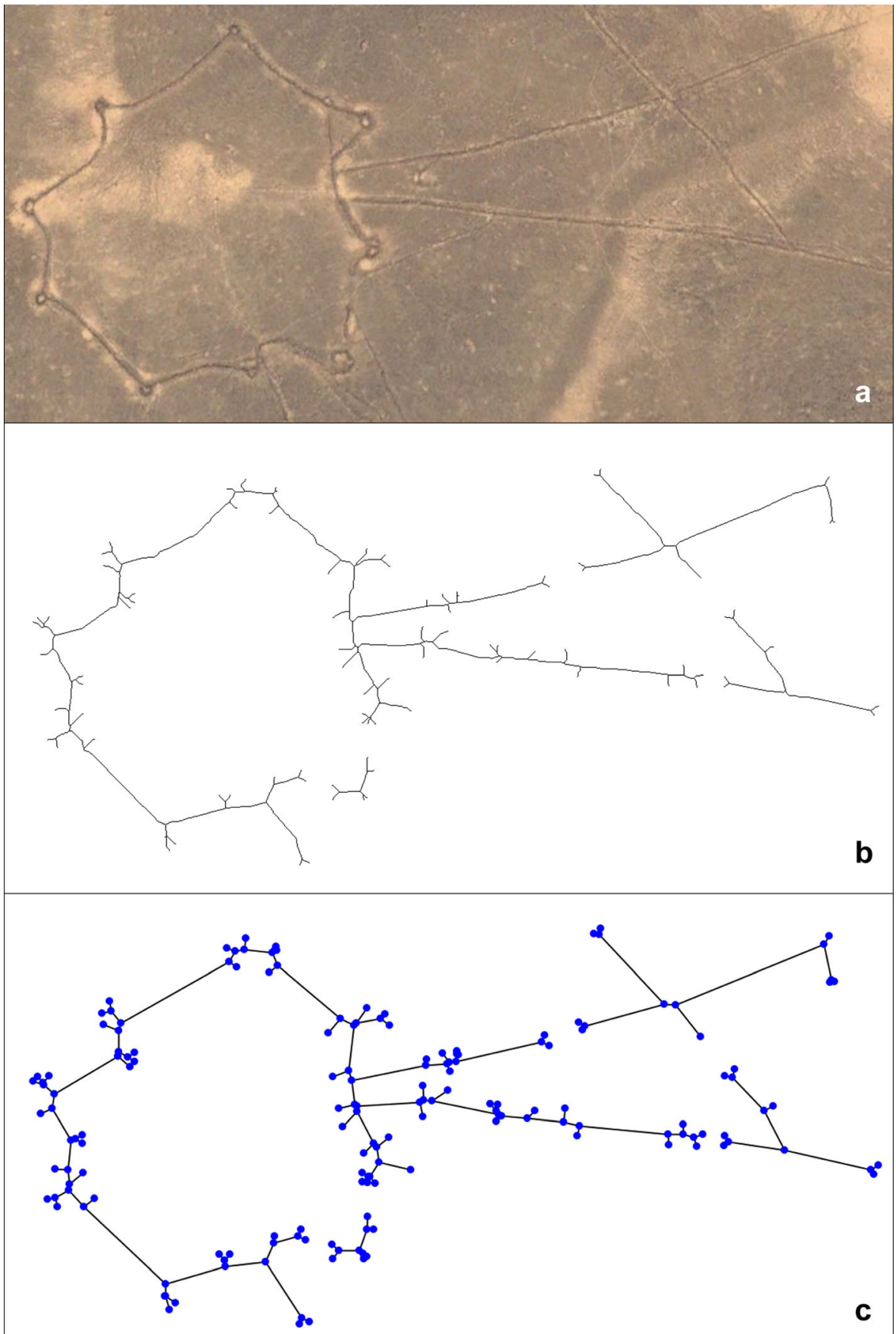

Fig. 10 Main steps of the kite recognition tool: $\mathbf{a}$ a kite as it appears on a satellite image, $\mathbf{b}$ the kite after image processing (segment detection and noise suppression), and $\mathbf{c}$ a graph representation of a kite

(a) extract the kite from the image using image processing tools, (b) represent the kite with a graph, and (c) compare the obtained graph with the prototypes of Step 1 to verify 
that it is really a kite (and not a river for example). Figure 10 illustrates the results of tasks 1 and 2 using the actual version of the tool under implementation.

To achieve these two steps, several challenges must be addressed. The first challenge is to identify the most appropriate graph representation of a kite. This representation must bring together the topological structure of the kite and its corresponding semantics. Then, it proposes efficient algorithms for matching the obtained representations. This turns into sorting, retrieving the algorithmic methods of graph matching, and then adapt them to the research issues of kite identification. A second challenge is to enable a kite identification that tolerates errors or imprecision in the query. Indeed, the kites have several forms depending on their state of preservation. Thus, it is suitable to offer approximate matching algorithms that express situations where kites are more or less preserved. A third challenge in this project is related to the complexity of the graph matching algorithms that have exponential execution time in the general case. However, for some subclasses of graphs, algorithms with polynomial complexity have been proposed. So it is important to identify subclasses of graphs corresponding to kites in order to apply the most efficient algorithms, or propose new algorithms.

Other application areas are also seeking and assessing basic tools for searching and comparison of structures represented by graphs. We can cite for example: biology and biochemical networks, organic and molecular chemistry, the analysis of documents, the semantic web and databases, etc. Thus developing an efficient and fast platform for recognizing objects by graph matching is an interesting scientific advance in the field of pattern recognition with applications in several domains.

\section{Final Remarks and Conclusions}

The kite is a landmark that reveals a way of occupying territory. It is an architectural feature of social groups, which hence left a reflection of their territory and catchment. However, these people have sometimes left very few traces enabling their identification. If the extent and density of these installations is taken into account, the kite is a massive phenomenon whose role was probably crucial in the development of societies in these arid regions. Therefore the perspective is inverted in relation to traditional archaeological research, where groups are most often identified by their domestic settlements, with their subsistence modes still undefined. The kites, as a phenomenon, are therefore a challenge for the archaeologist in that they require creative and new approaches. The approaches used by of the Globalkites project are multiple and complementary.

On the larger scale, digital tools (GIS and pattern recognition) could answer questions which have been scarcely addressed until now. The GIS this is at the core of the project, both due to its capacities in structuring inventories and to its ability to produce cartographic documents. This centrality also means that the relevance of results from analyses is still difficult to assess. The more related approaches (geoarchaeology, environmental studies, and archaeology) will have produced solid results (chronological data in particular), the more one will be able to mobilize the range of possible analyses with the GIS and the more results are likely to be relevant. Furthermore, the mathematical and IT processing approach for kite recognition will propose a collection of models for kites that can be used for other archaeological 
remains, provide answers to the questions surrounding kites and their environments, and develop approaches for the identification of kites. It will also provide new approaches for pattern recognition on images that can be adapted to different contexts and application frameworks, propose scalable pattern recognition algorithms, and finally validate these algorithms in a real application domain. Analyzing highresolution images to locate kites, carrying out a field survey to examine structures, excavation and sampling, are all stages in the process. The recording and the analysis of dusts might be what breaks new ground in the future when it comes to chronology. The results of surveying and dating, combined with a description of the kites in GIS data are to be analyzed concomitantly with the mapping of animal distribution, archaeozoological recording and the environmental information.

Obviously, the kites phenomenon, because of its global range, was probably more influential than previously thought. The human-animal relationships mediated by these constructions have both ecological implications (for instance the environmental impact of these activities), and socioeconomic ones (i.e. territorial demarcation and control). In order to better understand the actually recognized importance and particularly widespread distribution of this phenomenon, it will be useful to reassess data quality and to refocus studies both within a precise context and in a global perspective.

Acknowledgements GLOBALKITES research (2013-2016) is financed by the Agence Nationale de la Recherche, France (No. ANR-12-JSH3-0004-01, to RC). Kites shapes recognition program (2013-2016) is financed by a Labex IMU grant from the University of Lyon, France (to OB, CEB, HS, EV). We wish to thank the three reviewers for their very helpful comments, as well as Martin Makinson and Alicia Colson for English editing. For field work in Armenia, we thank Arkadi Karakhanyan, Iren Kalantaryan and Pavel Avetisyan. For field work in Kazakhstan, we thank Zhaken Taimagambetov, Renato Sala, Jean-Marc Deom and Constantin Plakhov. For a first visit in Jordan, we wish to acknowledge the help from Wael Abu-Azizeh and Mohammad Tarawneh.

\section{References}

Arkush, B. S. (1986). Aboriginal exploitation of pronghorn in the Great Basin. Journal of Ethnobiology, 6(2), 239-255.

Bălășescu, A., Vila, E., Radu, V., Badalyan, R., \& Chataigner, C. (2010). Production animale et économie de subsistence au Néolithique dans la plaine de l'Ararat (Arménie). Annales d'Université "Valahia" Târgovişte-Section d'Archéologie et d'Histoire, 12(1), 25-38.

Barge, O., \& Brochier, J.É. (2011). Visible from space, understood during the fieldwork: the example of "desert kites" in Armenia, Conference on cultural heritage and new technologies, November 2011, Vienna. http://www.stadtarchaeologie.at/?page id=3892. Accessed 14 April 2014.

Barge, O., Brochier, J.É., Chahoud, J., Chataigner, C., Chambrade, M.-L., Karakhanyan, A., Régagnon, E., Crassard, R. (2013). Towards a new approach to the 'kites phenomenon' in the Old World: the GLOBALKITES Project. Antiquity, 87(338), Project Gallery. Available at http://antiquity.ac.uk/projgall/ barge338/. Accessed 14 April 2014

Bärmann, E. V., Börner, S., Erpenbeck, D., Rössner, G. E., Hebel, C., \& Wörheide, G. (2013). The curious case of Gazella arabica. Mammalian Biology, 78, 220-225.

Baroin, C. (2006). La chasse et le statut des chasseurs au Sahara et en Arabie. In I. Sidéra, E. Vila, \& P. Erikson (Eds.), La chasse. Pratiques sociales et symboliques (pp. pp.87-pp.96). Paris: De Boccard.

Bar-Oz, G. (2004). Epipalaeolithic Subsistence Strategies in the Levant: A Zooarchaeological Perspective. Boston: Brill Academic.

Bar-Oz, G., \& Nadel, D. (2013). Worldwide large-scale trapping and hunting of ungulates in past societies. Quaternary International, 297, 1-7. 
Bar-Oz, G., Zeder, M., \& Hole, F. (2011). Role of mass-kill hunting strategies in the extirpation of Persian gazelle (Gazella subgutturosa) in the northern Levant. PNAS, 108(18), 7345-7350.

Bar-Yosef, O., \& Belfer-Cohen, A. (1989). The Origins of Sedentism and Farming Communities in the Levant. Journal of World Prehistory, 3(4), 447-498.

Benedict, J. B. (2011). Tundra Game Drives: an Arctic-Alpine Comparison. Arctic, Antarctic, and Alpine Research, 37(4), 425-434.

Berkes, F. (2008). Sacred Ecology (2nd ed.). New York: Routledge.

Betts, A. V. G. (Ed.). (1998). The Harra and the Hamad: excavations and surveys in eastern Jordan. Vol. 1, Sheffield Archaeological Monographs 9. Sheffield: Sheffield Academic Press.

Betts, A. V. G., \& Helms, S. (1986). Rock art in eastern Jordan: kite carvings? Paléorient, 12(1), 67-72.

Betts, A. V. G., \& Yagodin, V. (2000). Hunting traps on the Ustiurt plateau, Uzbekistan. In D. Christian \& C. Benjamin (Eds.), Realms of the Silk Roads: Ancient and Modern Silk Road Studies, 4 (pp. 29-45). Turnhout: Brepols.

Bin Aqil, A.J. (2004). Kneis l wa'el fi Hadramut [Hunting Caribou in Hadramout]. Sana'a/Riyadh: King Fahd National Library. [in Arabic]

Brink, J. W. (2013). The Barnett site: A stone drive lane communal pronghorn trap on the Alberta Plains, Canada. Quaternary International, 297, 24-35.

Brochier, J. É., Barge, O., Karakhanyan, A., Kalatarian, I., Chataigner, C., Chambrade, M.-L., \& Magnin, F. (2014). Kites on the margins: the Aragats kites in Armenia. Paléorient, 40(1), 25-53.

Brochier, J.É. (2002). Les sédiments anthropiques. Méthodes d'étude et perspectives. In J.C. Miskovsky (Ed), Géologie de la Préhistoire: méthodes, techniques, applications (pp. 453-477). Paris: GÉOPRÉ éditions.

Brochier, J.É. (2014) Des cercles de pierre dans la steppe, usages et chronologie. In C. Castel, O. Barge, N. Awad, \& M. Al-Maqdissi (Eds.) Des villes neuves aux franges du désert de Syrie à la fin du $3^{e}$ millénaire : Travaux de la mission archéologique franco-syrienne d'Al-Rawda 2002-2008; Travaux de la mission syrienne de Tell Sha'irat 2007-2008 et Tell Es Sour 2009, Travaux de la Maison de 1'Orient. Lyon: Maison de l'Orient (in press).

Brochier, J. É., \& Thinon, M. (2003). Calcite crystals, starch grains aggregates or.POCC? Comment on 'calcite crystals inside archaeologial plant tissues'. Journal of Archaeological Science, 30(9), 1211-1214.

Brunner, U. (2008). Les pièges de chasse antiques au Yémen. Chroniques Yéménites, 15, 29-34.

Bunke, H., \& Riesen, K. (2011). Recent advances in graph-based pattern recognition with applications in document analysis. Pattern Recognition, 44, 1057-1067.

Burckhardt, J. L. (1831). Notes on the Bedouins and Wahabys, collected during his travels in the east. Association for Promoting the Discovery of the Interior of Africa (Vol. 2). London: Colburn and Bently.

Chahoud, J., \& Vila, E. (2011). The role of animals in ancient Sidon: an overview of ongoing zooarchaeological studies. Archaeology and History in the Lebanon, 34(35), 259-284.

Chapelle, J. (1957). Nomades noirs du Sahara. Paris: Plon (Re-edited: 1982, Paris: L'Harmattan).

Custred, G. (1979). Hunting technologies in Andean culture. Journal de la Société des Américanistes, 66, 719.

D'Hont, O. (1994). Vie quotidienne des 'Agēdāt'. Techniques et occupation de l'espace sur le MoyenEuphrate. Damascus: IFPO

Davis, S. J. M. (1982). Climatic change and the advent of domestication the succession of ruminant artiodactyls in the Late Pleistocene-Holocene in the Israel region. Paléorient, 8(2), 5-15.

Degen, D. E. (2010). A hunting scene from the Negev: the depiction of a desert kite and throwing weapon. Israel Exploration Journal, 60(2), 146-165.

Deom, J., Sala, R. (2009). Ancient wild game management in arid regions: new evidences from the Northern Ustyurt Plateau (Kazakhstan), In B.T. Zhanaev (Ed.) Nauchnye chteniya pamyati N.E. Masanova: sbornik materialov nauchno-prakticheskoi konferentsii Almaty 25-26 Aprelya 2008 (pp. 135-141). Almaty: DaikPress. [Original in Russian]. http:/www.lgakz.org/Texts/LiveTexts/Ustyurt\%20traps\%202009.pdf. Accessed 15 April 2014.

Desombre, S. (1946). La guémira : Mission Alger-Lac Tchad 1937. Paris: Lesourd.

Develle, A.-L., Gasse, F., Vidal, L., Williamson, D., Demory, F., Van Campo, E., Ghaleb, B., \& Thouveny, N. (2011). A 250ka sedimentary record from a small karstic lake in the Northern Levant (Yammoûneh, Lebanon). Palaeogeography, Palaeoclimatolology, Palaeoecology, 305(1-4), 10-27.

Dong, Q., Yang, X., Zhao, J., \& Tang, Y. Y. (2008). Embedding a family of disjoint 3D meshes into a crossed cube. Information Sciences, 178, 2396-2405.

Doughty, C.M. (1931). Arabia deserta. Textes choisis par Edward Garnett. London: Jonathan Cape (French translation: 1990, Paris: Payot).

Dupré, G. (1976). La chasse au filet chez les Nzabi (République Populaire du Congo). Cahiers ORSTOM, 13 (4), 343-355. 
Échallier, J.-C., \& Braemer, F. (1995). Nature et fonction des "Desert Kites": données et hypothèses nouvelles. Paléorient, 21(1), 35-63.

Emms, D., Wilson, R. C., \& Hancock, E. (2007). Graph embedding using quantum commute times. In F. Escolano \& M. Vento (Eds.), Graph-Based Representations in Pattern Recognition (pp. 371-382). Berlin: Springer.

Fowden, G. (1999). 'Desert kites': ethnography, archaeology and art. In: Humphrey, J.H. (Ed.), The Roman and Byzantine Near East: Some Recent Archaeological Research vol. 2. Journal of Roman Archaeology: Supplementary Series, 31, 107-136

Gärtner, T., Flach, P., \& Wrobel, S. (2003). On graph kernels: Hardness results and efficient alternatives. In B. Schölkopf \& M. K. Warmuth (Eds.), Learning Theory and Kernel Machines (pp. 129-143). Berlin: Springer.

Gasparyan, B., Khechoyan, A., Bar-Oz, G., Malkinson, D., Nachmias, A., Nadel, D. (2013). The northernmost kites in south-west Asia: the fringes of the Ararat Depression (Armenia) Project. Antiquity, 87(336), Project Gallery. http://antiquity.ac.uk/projgall/bar-oz336/. Accessed 14 April 2014.

Gordon, B. C. (1990). World rangifer communal hunting. In L. Davis \& B. Reeves (Eds.), Hunters of the recent past (pp. 277-303). London: Routledge.

Gourichon, L. (2004). Faune et saisonnalité : l'organisation temporelle des activités de subsistance dans l'Épipaléolithique et le Néolithique précéramique du Levant nord (Syrie). Unpublished $\mathrm{PhD}$ dissertation. Lyon: Université Lyon 2. http://theses.univ-lyon2.fr/documents/lyon2/2004/gourichon_1\#p=0\&a=top. Accessed 14 April 2014.

Gourichon, L., Helmer, D., \& Peters, J. (2006). À la croisée des pratiques cynégétiques et de l'iconographie des animaux sauvages. Haut et Moyen Euphrate $\mathrm{X}^{\mathrm{e}}$ et $\mathrm{IX}^{\mathrm{e}}$ millénaires av. In I. Sidéra, E. Vila, \& P. Erikson (Eds.), La chasse. Pratiques sociales et symboliques (pp. pp. 107-pp. 123). Paris: De Boccard.

Grigson, C. (1987). Shiqmim: pastoralism and other aspects of animal management in the Chalcolithic of the northern Negev. In T. E. Levy \& I. Shiqmim (Eds.), British Archaeological Report, International Series 356. Oxford: Archaeopress.

Grigson, C. (2006). Farming? Feasting? Herding? Large mammals from the Chalcolithic of Gilat. In T. E. Levy (Ed.), Archaeology, Anthropology and Cult. The Sanctuary at Gilat, Israel (pp. pp. 215-pp. 319). London: Equinox.

Harding, G. L. (1953). The cairn of Hani. Annual of the Department of Antiquities of Jordan, 2, 8-56.

Harrison, D. L. (1968). The Mammals of Arabia (Vol IIth ed.). London: Ernest Benn Ltd.

Haussler, D. (1999). Convolution kernels on discrete structures. UCSC-CRL-99-10. Technical report, UC Santa Cruz. Santa Cruz, CA: University of California.

Helmer, D., Gourichon, L., \& Stordeur, D. (2004). À l'aube de la domestication animale. Imaginaire et symbolisme animal dans les premières sociétés néolithiques du Nord du Proche- Orient. Anthropozoologica, 39(1), 143-163.

Helmer, D., Roitel, V., Saña Segui, M., Willcox, G. (1998). Interprétations environnementales des données archéozoologiques et archéobotaniques en Syrie du Nord de 16000 BP à 7000 BP, et les débuts de la domestication des plantes et des animaux. In M. Fortin, O. Aurenche (Eds.), Espace naturel, espace habité en Syrie du Nord $\left(10^{e}-2^{e}\right.$ millénaires av. J-C.) (pp. 9-33). Canadian Society for Mesopotamian Studies, Bulletin 33, Travaux de la Maison de l'Orient 28, Lyon: Maison de l'Orient, Toronto: CSMS.

Helms, S., \& Betts, A. V. G. (1987). The Desert "Kites" of the Badiyat Esh-Sham and North Arabia. Paléorient, 13(1), 41-67.

Hershkovitz, I., Ben-David, Y., Arensburg, B., Goren, A., \& Pinchasov, A. (1987). Rock engravings in southern Sinai. In G. Gvirtzman, A. Shmueli, Y. Gardos, I. Beit-Arieh, \& M. Harel (Eds.), Sinai Part 2, Human Geography / Gvirtzman Gdaliahu (pp. 605-616). Givatayim: Eretz Ha-Tzvi.

Holzer, A., Avner, U., Porat, N., \& Horwitz, L. K. (2010). Desert kites in the Negev desert and northeast Sinai: Their function, chronology and ecology. Journal of Arid Environments, 74(7), 806-817.

Horwitz, L. K., Tchernov, E., Mienis, H. K., Hakker-Orion, D., \& Bar-Yosef Mayer, D. E. (2002). The archaeozoology of three Early Bronze Age sites in Nahal Besor, northwestern Negev. In E. C. M. van den Brink \& E. Yanai (Eds.), In quest of ancient settlements and landscapes. Archaeological studies in honour of Ram Gophna (pp. pp. 107-pp. 133). Tel Aviv: Ramot Publishing.

Horwitz, L. K., Tchernov, E., \& Mienis, H. K. (2001). Archaeozoology and archaeomalacology of site 917 in the 'Uvda Valley. Atiqot, 42, 121-127.

Hoyland, R. G. (2001). Arabia and the Arabs: from the Bronze Age to the coming of Islam. London: Routledge.

Ingold, T. (1980). Hunters, Pastoralists and Ranchers. Reindeer economies and their transformations. Cambridge, UK: Cambridge University Press. 
Issar, A. S., \& Zohar, M. (2007). Climate change: environment - Environment and History of the Near East (2nd ed.). New York. Berlin Heidelberg: Springer-Verlag.

Jabbur, J.S., \& Conrad, L.I. (1995). The bedouins and the desert: aspects of nomad life in the Arab East. New Yتاب ابدو' York: Sunny Press, State University of New York Press. [Translated from Jabbur J.S. 1988 'و ابادية]

Kempe, S., \& Al-Malabeh, A. (2013). Desert kites in Jordan and Saudi Arabia: Structure, statistics and function, a Google Earth study. Quaternary International, 297, 126-146.

Kennedy, D. (2012). Kites- new discoveries and new type. Arabian archaeology and epigraphy, 23, $145-155$.

Kennedy, D., \& Bishop, M. C. (2011). Google Earth and the archaeology of Saudi Arabia. A case study from the Jeddah area. Journal of Archaeological Science, 38(6), 1284-1293.

Kingswood, S. C., \& Blank, D. A. (1996). Gazella subgutturosa. Mammalian Species, 518, 1-10.

Kobusiewicz, M. (1999). Excavations at Sinai-10, the Kite Site, Romythi locality. In F. Eddy \& F. Wendorf (Eds.), An archaelogical investigation of the Central Sinai (pp. 173-180). Boulder: University Press of Colorado.

Lagraa, S., Seba, H., Khennoufa, R., M'Baya, A., \& Kheddouci, H. (2014). A distance measure for large graphs based on prime graphs. Pattern Recognition, 47, 2993-3005.

Le Quellec, J.-L., \& Civrac, M.-A. (2010). La chasse au filet sur les peintures rupestres du Sahara central et dans l'Antiquité. Cahier de l'AARS (Association des Amis de l'Art Rupestre Saharien), 14, 255262.

Legge, A. J., \& Rowley-Conwy, P. A. (1987). Gazelle killing in Stone Age Syria. Scientific American, 255(8), 88-95.

Legge, A. J., \& Rowley-Conwy, P. A. (2000). The exploitation of animals. In A. M. T. Moore, G. C. Hillman, \& A. J. Legge (Eds.), Village on the Euphrates (pp. 423-471). Oxford: Oxford University Press.

Lerp, H., Wronski, T., Butynski, T. M., \& Plath, M. (2013). Speciation of Arabian gazelles. In P. Michalak (Ed.), Speciation: Natural Processes, Genetics and Biodiversity (pp. 59-82). New York: Nova Science.

MacDonald, M.C. (2005). Of Rock-art, 'Desert Kites' and Mesayid. In A.V. Sedov, I.M. Smulyanskaya (Eds.), Arabia Vitalis: Arabskij Vostok, Islam, drevnyaya, Araviya: Sbornik Naychnykh statej, posvyashchennyj 60-letiyu V.V. Naumkina (pp. 332-345). Moscow: Rossijskaya Akademiya Nauk

Maitland, R. A. (1927). The 'works of the old man' in Arabia. Antiquity, 1, 197-203.

Martin, L. (1998). The faunal remains from Dhuweila. In A. V. G. Betts (Ed.), Harra and the Hammad: Archaeological Explorations in the Jordanian Basalt Desert (pp. 159-184). Sheffield: Sheffield University Press.

Martin, L. (2000a). Gazelle (Gazella sp.) behavioural ecology: predicting animal behaviour for prehistoric environments in southwest Asia. Journal of Zoology, 250, 13-30.

Martin, L. (2000b). Mammal remains from the eastern Jordanian Neolithic, and the nature of caprine herding in the steppe. Paléorient, 25(2), 87-104.

Martin, L., McCorriston, J., Crassard, R. (2009). Early Arabian pastoralism at Manayzah in Wadi Sana, Hadramawt. Proceedings of the Seminar for Arabian Studies, 39, 271-282.

Mashkour, M., \& Vila, E. (2003). Archaeometrical approaches for tracking ancient Bedouins; a pilot project in northern Mesopotamia from 4th to 1st millennia B.C. In T. Herzog, W. Holzwarth (Eds.), Orientwissenschaftliche Hefte. Mitteilungen des SFB "Differenz und Integration" 4/1/ Nomaden und Sesshafte - Fragen, Methoden, Ergebnisse (pp. 1-20). Halle (Saale): Orientwissenschatliche Zentrum der Martin-Luther-Universität Halle-Wittenberg, Heft 9.

Migowski, C., Stein, M., Prasad, S., Negendank, J. F. W., \& Agnon, A. (2006). Holocene climate variability and cultural evolution in the Near East from the Dead Sea sedimentary record. Quaternary Research, 66, 42-431.

Monks, G. G. (1981). Seasonality studies. In M. B. Schiffer (Ed.), Advances in archaeological method and theory (pp. 177-240). New York: Academic Press.

Morandi Bonacossi, D., \& Iamoni, M. (2012). The Early History of the Western Palmyra Desert Region The Change in the Settlement Patterns and the Adaptation of Subsistence Strategies to Encroaching Aridity: A First Assessment of the Desert-kite and Tumulus Cultural Horizons. Syria, 89, 31-58.

Musil, A. (1928). The manners and customs of the Rwala Bedouins. Oriental Explorations and Studies 6. New York: American Geographical Society.

Nadel, D., Bar-Oz, G., Avner, U., Boaretto, E., \& Malkinson, D. (2010). Walls, ramps and pits: the construction of the Samar Desert kites, southern Negev, Israel. Antiquity, 84(326), 976-992.

Nadel, D., Bar-Oz, G., Avner, U., \& Malkinson, D. (2013). Ramparts instead of walls: building techniques of large game traps (kites) in the Negev Highland. Quaternary International, 297, 147-154.

Perevolotsky, A., \& Baharav, D. (1991). The distribution of desert kites in eastern Sinai and sub-regional carrying capacity: an ecological perspective. Journal of Arid Environments, 20, 239-249. 
Peters, J., Driesch, A. von den, Helmer, D. (2005). The Upper Euphrates-Tigris Basin: Cradle of agropastoralism? In J.-D. Vigne, J. Peters, D. Helmer (Eds.) The first steps of animal domestication, Proceedings of the 9th International Council of Archaeozoology (ICAZ) Conference (Durham, 2002) (pp. 96-123). Oxford: Oxbow Books.

Picalause, P., Cauwe, N., Lemaitre, S., Vander Linden, M., \& Van Berg, P. L. (2004). Desert-kites of the Hemma plateau (Hassake, Syria). Paléorient, 30(1), 89-99.

Quenet, P., \& Chambrade, M.-L. (2013). Nouveaux kites en Jezireh syrienne. Studia Orontica, XI, 61-76.

Reed, C. A. (1965). Imperial Sassanian hunting of pig and fallow deer, and problems of the survival of these animals today in Iran. Postilla, 92, 1-23.

Rees, L. W. B. (1929). The Trans-Jordan deserts. Antiquity, 3, 389-407.

Riemer, H. (2009). Prehistoric trap hunting in the eastern Sahara deserts: A re-evaluation of the game trap structures. In H. Riemer, F. Förster, N. Pöllath, \& M. Herb (Eds.), Desert animals in the eastern Sahara: Status, economic significance, and cultural reflection in antiquity (pp. 175-188). Köln: Heinrich-BarthInstitut.

Robinson, S. A., Black, S., Sellwood, B. W., \& Valdes, P. J. (2006). A review of palaeoclimates and palaeoenvironments in the Levant and Eastern Mediterranean from 25,000 to 5000 years BP: setting the environmental background for the evolution of human civilization. Quaternary Science Reviews, 25, $1517-1541$.

Rodier, X., Barge, O., Saligny, L., Nuninger, L., \& Bertoncello, F. (2011). Information spatiale et archéologie. Paris: Errance.

Sapir-Hen, L., Bar-Oz, G., Khalaily, H., \& Dayan, T. (2009). Gazelle exploitation in the early Neolithic site of Motza, Israel: the last of the gazelle hunters in the southern Levant. Journal of Archaeological Science, 36(7), 1538-1546.

Sergeant, R. B. (1976). South Arabian hunt. London: Luzac.

Sinclair, W. F., \& Fergusson, D. (1902). The travels of Pedro Teixeira: with his "Kings of Harmuz" and extracts from his "Kings of Persia". London: Hakluyt Society.

Skorupka, M. (2010). Les “desert kites” yéménites, une relecture critique des données. Chroniques Yéménites, 16, 5-14.

Smith, B. D. (2013). Modifying landscapes and mass kills: Human niche construction andcommunal ungulate harvests. Quaternary International, 297, 8-12.

Smol, J. P. (1985). The ratio diatom frustules to chrysophycean statospores: a useful palaeolimnological index. Hydrobiologia, 123, 199-204.

Speth, J. D. (2013). Middle Paleolithic large-mammal hunting in the southern Levant. In J. L. Clarck \& J. D. Speth (Eds.), Zooarchaeology and Modern Human origins: Human hunting behavior during the Later Pleistocene (pp. 19-43). Dordrecht: Springer.

St Simpson, J. (1994). Gazelle-hunters and Salt-collectors: A Further Note on the Solubba. Bulletin of the American School of Oriental Research, 293, 79-81.

Storemyr, P. (2011). The ancient stone-built game traps at Gharb Aswan and beyond, Lower Nubia and Upper Egypt. Sahara, 22, 15-28.

Tsahar, E., Izhaki, I., Lev-Yadun, S., \& Bar-Oz, G. (2009). Distribution and extinction of ungulates during the Holocene of the southern Levant. PLoS ONE, 4(4), e5316.

Uerpmann, M. (2008). Neolithic Faunal Remains from al-Buhais 18 (Sharjah, UAE). In H.-P. Uerpmann \& S. Jasim (Eds.), The Natural Environment of Jebel al-Buhais: Past and Present. The Archaeology of Jebel al-Buhais, Sharjah, United Arab Emirates (2nd ed., pp. (pp. 97-132). Tübingen: Kerns Verlag.

Ur, J., \& Hammer, E. (2009). Pastoral nomads of the 2nd and 3rd millennia A.D. on the Upper Tigris River, Turkey: the Hirbemerdon Tepe Survey. Journal of Field Archaeology, 34(1), 37-56.

van de Sande, K. E. A., Gevers, T., \& Snoek, C. G. M. (2010). Evaluating Color Descriptors for Object and Scene Recognition. IEEE Transactions on Pattern Analysis and Machine Intelligence, 32(9), 1582-1596.

Verheyden, S., Nader, F. H., Cheng, H. J., Edwards, L. R., \& Swennen, R. (2008). Paleoclimate reconstruction in the Levant region from the geochemistry of a Holocene stalagmite from the Jeita cave, Lebanon. Quaternary Research, 70, 368-381.

Vila, E. (1991). Note sur un dépôt de gazelles dans une fosse uruk d'El Kowm 2-Caracol (Syrie). Cahiers de l'Euphrate, 8, 55-60.

Vila, E. (1998). L'exploitation des animaux en Mésopotamie aux $I^{e}$ et III millénaires avant J.-C. Monographie du CRA 21. Paris: CNRS Éditions.

Vila, E. (2004). Apport de l'étude de la faune à la connaissance des modes de vie. In F. Braemer, J.-C. Échallier, \& A. Taraqji (Eds.), Khirbet al Umbashi, Villages et campements de pasteurs dans le "désert noir" (Syrie) à l'âge du Bronze (pp. 271-288). Beirut: IFPO. 
Vila, E. (2006). Données archéozoologiques de la période Halaf à l’Âge du Fer. In B. Lion \& C. Michel (Eds.), De la domestication au tabou: le cas des suidés au Proche-Orient ancien (pp. 137-153). Paris: De Boccard.

Vila, E., \& Al Besso, M. (2014). L'homme et la steppe au Bronze ancien IV. Étude archéozoologique. In C. Castel, O. Barge, N. Awad, \& M. Al-Maqdissi (Eds.), Des villes neuves aux franges du désert de Syrie à la fin du $3^{e}$ millénaire: Travaux de la mission archéologique franco-syrienne d'Al-Rawda 2002-2008; Travaux de la mission syrienne de Tell Sha'irat 2007-2008 et Tell Es Sour 2009, Travaux de la Maison de l'Orient. Lyon: Maison de l'Orient (in press).

Vila E., \& Helmer, D. (2014). The expansion of sheep herding and the development of wool production in the ancient Near East: an archaeozoological and iconographical approach. In C. Bréniquet, C. Michel (Eds.), Wool economy in the ancient Near East and the Aegean: from the beginnings of sheep husbandry to institutional textile industry (pp. 22-40). Oxford: Oxbow Books.

Wright, W. (1895). An account of Palmyra and Zenobia with travels and adventures in Bashan and the desert. London: T. Nelson Edition.

Zeder, M. A., Bar-Oz, G., Rufolo, S., \& Hole, F. (2013). New perspectives on the use of kites in mass-kills of Levantine gazelle: a view from northeastern Syria. Quaternary International, 297, 110-125. 